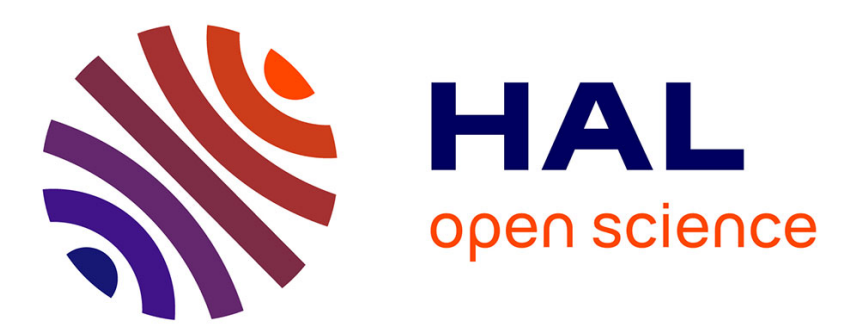

\title{
The heritage of Dugald Stewart: Oxford philosophy and the method of political economy
}

\author{
Pietro Corsi
}

\section{To cite this version:}

Pietro Corsi. The heritage of Dugald Stewart : Oxford philosophy and the method of political economy. 1988. halshs-00002895v3

\section{HAL Id: halshs-00002895 \\ https://shs.hal.science/halshs-00002895v3}

Preprint submitted on 7 Jun 2006

HAL is a multi-disciplinary open access archive for the deposit and dissemination of scientific research documents, whether they are published or not. The documents may come from teaching and research institutions in France or abroad, or from public or private research centers.
L'archive ouverte pluridisciplinaire HAL, est destinée au dépôt et à la diffusion de documents scientifiques de niveau recherche, publiés ou non, émanant des établissements d'enseignement et de recherche français ou étrangers, des laboratoires publics ou privés. 


\title{
THE HERITAGE OF DUGALD STEWART : OXFORD PHILOSOPHY AND THE METHOD OF POLITICAL ECONOMY*
}

\author{
PIETRO CORSI \\ Harvard University
}

\section{RIASSUNTO}

L'articolo esamina il dibattito sulla metodologia dell'economia politica che anima i circoli intellettuali anglicani degli inizi del diciannovesimo secolo. Ad Oxford, l'approccio all'economia politica era fortemente condizionato dalla riflessione critica sulle proposte epistemologiche avanzate da Dugald Stewart nel suo Elements of the Philosophy of the Human Mind. I pensatori dell'Oriel College che presero parte al dibattito erano preoccupati dal processo di rapida trasformazione della società inglese, e dall'emergere di fonti di autorità culturale indipendenti dalla, se non apertamente contrarie alla Chiesa Anglicana ed alle Universita. La discussione della metodologia dell'economia politica investiva dunque diversi aspetti dalla vita sociale ed intellettuale del tempo.

Il dibattito oxoniense ruotava intorno al parallelismo che molti credevano di notare tra il metodo della meccanica razionale e quello dell'economia politica. Pur avallando le pretese di scientificità avanzate dagli economisti classici, i docenti di Oxford negavano che $i$ risultati ottenuti in economia politica fossero immediatamente applicabili alla realtà sociale : al pari dei cultori della meccanica razionale, l'economista doveva tenere presenti le « frizioni » generate dalle esistenti strutture politiche e sociali.

A Cambridge, William Whewell e Richard Jones valutavano con preoccupazione la difesa dell'economia politica elaborata dai colleghi di Oxford. A loro avviso, gli studiosi dell'Oriel College concedevano troppo all'economia politica ricardiana. Alla fine degli anni venti del

\footnotetext{
*A version of this article was published in : Istituto e Museo di Storia della scienza Firenze, Nuncius, Annali di storia della scienza, anno 11, 1987, fasc. 2, Firenze, Leo S. Olschki editore, 1988
} 
diciannovesimo secolo, gli intellettuali cantabrigensi sottoposero a critica severa il preteso parallelismo tra meccanica razionale ed economia politica che i seguaci di Ricardo e i docenti di Oxford ponevano al centro delle loro riflessioni. L'economia politica, si diceva a Cambridge, era una disciplina troppo giovane per poter assumere procedure assiomatico-deduttive. Laboriose ricerche erano ancora da intraprendere, prima che si potesse procedere alla costruzione di un sistema di economia teorica.

Il presente saggio sottolinea la centralità di Dugald Stewart nel dibattito sulla metodologia dell'economia politica dei primi decenni del diciannovesimo secolo. Si sostiene inoltre che la lettura critica delle tesi epistemologiche avanzare dallo Stewart rappresentò un momento cruciale nella elaborazione della metodologia dell'economia politica proposta da John Stuart Mill. I risultati di questo studio impongono una revisione delle interpretazioni classiche dei dibattiti filosofici e culturali in genere del primo Ottocento inglese.

This paper examines the debate over the methodology of political economy that took place in Britain during the early decades of the nineteenth century. It is my contention that the group of Oxford intellectuals known as the " Oriel Noetics ", led by Edward Copleston (1776-1849), Provost of Oriel College from 1814 to 1826, and Richard Whately (1787-1863), a Fellow of Oriel and Archbishop of Dublin from 1831 to 1863, saw the debate as part of a broader discussion of the Scottish philosophy of the human mind. The work of Nassau William Senior (1790-1864), the first Professor of Political Economy at Oxford (from 1825 to 1830), was greatly influenced by the philosophical views of Dugald Stewart and of his own Oriel teachers. For Copleston, Whately, and Senior, Stewart's Elements of the Philosophy of the Human Mind - in particular the second volume - presented an epistemological scheme of reference for their approach to theology, science, and political economy. I suggest also that Stewart's influence went beyond the group of Oxford Noetics. Explicit and implicit references to his methodology of science can be traced in works by William Whewell (1794-1866), Richard Jones (1790-1855), and James (1773-1836) and John Stuart Mill (1806-1873).

The contribution of the Oxford Noetics to the study of political economy has been analyzed in some detail by distinguished historians. The work of Nassau Senior has been given particular attention, due to 
the intrinsic interest of the thesis he defended concerning Malthusian law, the methodology of political economy, and the relationship between the science of economics and economic legislation. Whately's Introductory Lectures on Political Economy, delivered at Oxford in Easter Term 1831, has also attracted attention. Copleston, Whately, and Senior took part in many debates about politics, economics, and society. Their concerns ranged from the bullion controversies to the poor-law reform movement, from the commutation of tithes to economic and ecclesiastical policies in Ireland as well as to issues like colonization and the defense of political economy from the charge of being unfriendly to revealed religion. This activity has been much commented on by historians of various disciplines. There is, however, no comprehensive study available of the overall significance of the Oxford Noetics in early nineteenth-century British intellectual life. (1)

In a seminal paper published thirty years ago, Professor S. G. Checkland reconstructed the debates over the establishment of political economy as an academic discipline. He drew a suggestive picture of the political, theological, and social preoccupations underlying reactions to political economy in Anglican circles, rightly stressing the importance of Edward Copleston and Richard Whately in the diffusion of political economy among Church leaders and English academics. Checkland emphasized the need for a comprehensive approach to the discussion in which the Oxford Noetics were involved. His suggestion has not been taken up by subsequent commentators, however, who have chosen to concentrate on one or the other member of the group. (2)

It is of course impossible to undertake here a detailed reconstruction of the Oriel strategy in the context of the theological, scientific, philosophical, and political debates of the time, but one can offer an idea of the kind of issues relevant to such an enterprise, and the kind of results likely to be achieved. The attempt will emphasize hitherto unnoticed or scarcely attended to dimensions of the debate on the method of political economy.

(1) See P. Corsi, 1987a, for a discussion of selected features of the Noetic teaching, with particular reference to theology, philosophy, and church politics, and the relevant bibliography. On Nassau Senior, see the classic Bowley 1937 ; Levy 1970 has made use of an important collection of manuscripts, now partially recovered by the National Library of South Wales, Aberystwyth. For the vicissitudes of the Senior papers, see Gwynn Jenkins, "The Nassau Senior Papers » typewritten text, in the Senior Papers, National Library of South Wales. I am grateful to Mr. Jenkins for his assistance during my visit to Aberystwyth. On Whately's and Senior's contribution to contemporary political economy see Schumpter 1954 ; See also Rashid 1977, 1978, 1983 ; Waterman 1983, McKerrow 1978, 1981, 1982 ; Akenson 1971 ; McDowell 1952 ; Poynter 1969 ; Cowherd 1977 ; Hilton 1977 ; Soloway 1969 and Ward 1972.

(2) Checkland 1951. 


\section{Dugald Stewart and Oxford}

There is a consensus among historians of science, philosophy, and economics that the influence of Dugald Stewart on early nineteenth-century British culture needs a thorough assessment. There are few such studies available, and the ones that do exist are not free from serious defects. A few years ago Richard Olson published a suggestive work on the relevance of Scottish epistemology - Stewart's in particular - to the development of British physics in the early and middle decades of the nineteenthcentury, but the validity of his thesis was to some extent obscured by the rhapsodic nature of the evidence he offered concerning the actual channels that brought the Scottish philosopher's ideas to the attention of English physicists, some of whom were active more than thirty years after Stewart's death. In his recent study of what he called " young Darwin's cultural circle », Edward Manier noted the relevance of Stewart's philosophy to Darwin's discussion of ethical and metaphysical issues. He pointed out that the presence of Stewart's ideas in early nineteenth-century British philosophical debates has been poorly explored by historians of the period. Finally, in a paper delivered at the King's College Research Center in 1980 Professor Donald Winch reminded his audience of the determinant influence exercised by Stewart's pupils on various domains of intellectual activity through the agency of « the main organ of the Whig intelligentsia », the Edinburgh Review. (3)

After the completion of this contribution in 1981, several scholars have tackled the issue of the relevance of Stewart to the understanding of important sectors of British intellectual life in the early nineteenth-century. Several recently appeared studies stemmed out of the King's College Colloquium of 1981, and will be referred to where appropriate. Research independently carried by other colleagues is creating a growing awareness of the centrality of epistemological debates for various features of British culture at the period under investigation. Our concentration on the Oriel Noetics will add a new dimension to the endeavor of reconsidering philosophical, theological and political debates during the early decades of the nineteenth century.

The success of Stewart's ideas within the circle of Edinburgh reviewers, who were notoriously unfriendly toward Tory High Churchmen and the southern academics, would appear to exclude a priori the possibility of his popularity among Oxford intellectuals. Edward Copleston

(3) Segernedt 1935 ; Olson 1975 ; Manier 1977 ; Kavaloski 1974 ; Winch 1983. 
and the Oriel dons had suffered particularly elaborate vituperation from various writers in the Edinburgh Review. Copleston could not have been pleased to find himself described as a "grammatical shopkeeper, who has occupied half his life in watching whether Oriel had more gentlemen commoners than Corpus : or by how many pounds a tutor's place at Trinity was superior to a similar office at Wadham ». (4)

Yet a close look at works by Copleston, Whately, and their pupils, as well as at reviews of Stewart's works in Tory and High Church journals, reveals that Stewart found a sympathetic, albeit critical, hearing there. Indeed, when Stewart was attacked by Francis Jeffrey in the Edinburgh Review, it was the Quarterly that came to the rescue. The Oxford academics sided with their Scottish colleague in defending the philosophy of the human mind from the charge that it was useless for the advancement of knowledge and human happiness. (5)

The links between Oriel and Edinburgh were intellectual and personal. To consider the latter first, it is appropriate to recollect that John William Ward (1781-1833), the first Earl of Dudley, was Stewart's pupil and from 1797 to 1799 actually a member of Stewart's household. When Ward moved to Oxford he was placed under the tutorship of Copleston at Oriel. Ward's letters to Copleston and to "Ivy ", as the young student affectionately called Mrs. Dugald Stewart, show that he acted as an intermediary between the Scottish philosopher and the Fellow who later became Provost of Oriel. Ward urged upon Copleston the need for academic reform at Oxford, which had become notorious for its intellectual sluggishness and educational inefficiency. He preached Stewart's gospel of adjusting institutions to the needs of the time and repeated his warnings about the danger of leaving political and social debate to subversive demagogues. Conversely, Ward kept Stewart informed of Copleston's publications, and assured his old teacher that Copleston « devours eagerly all that proceeds for the pen of Mr. Stewart ». (6)

Of Stewart's works, the one that pleased the High Church most, and the Oxford Noetics in particular, was the Philosophical Essays, which appeared in 1810. His Life of Reid (1823) was also well received, but the polemical thrust of the Essays particularly pleased the southern critics. Stewart offered sophisticated arguments that could be used to counteract the revival by Thomas Belsham (1750-1829) of Priestleian

(4) (Knight et al.) 1810, p. 184.

(5) (Jeffrey) 1810 ; (Lyall) 1811 and 1815

(6) Romilly 1905. 
philosophical necessity, Erasmus Darwin's psychological materialism, and the daring critique of ethical and metaphysical categories elaborated by John Horne Tooke through the etymological analysis of philosophical language. These developments, coupled with the growing popularity of Unitarian philosophy and theology, had made it appear that intellectual indictment, defeated at the political level, was mounting a dangerous attack in philosophy and science. Such tendencies were apparently receiving authoritative support and inspiration from the followers of Marie Jean A.N.C. de Condorcet and Etienne Bonnôt de Condillac (1714-1780) in France, and from the school of the idéologues in particular. Stewart's critique of the idéologues, his vindication of the autonomy of the philosophy of the human mind, and his refutation of the attempts to reduce the operations of the human mind to physiological or anatomical functions provided Christian apologists with strong arguments against their theological and political opponents. (7)

When Ward and Copleston wrote a joint review of the Life of John Home Tooke for the Quarterly Review they drew on Stewart's Essays for a refutation of Tooke's etymological and philosophical crudities, and other works published during the $1810 \mathrm{~s}$ and 1820 s by Whately, Copleston, and some of their pupils, notably Baden Powell (1796-1860) and Samuel Hinds (1793-1872), also contained favorable remarks about Stewart. It was clear to contemporaries, as it is to the historian, that the philosophical strategy adopted by Copleston and Whately in their polemical works was greatly indebted to Stewart's Essays, his Outlines of Moral Philosophy (1793), and the Elements of the Philosophy of the Human Mind (1792, 1814, 1827). (8)

The Oxford response to Stewart was not uncritical. Indeed, there was one point on which " the school of speculative philosophy », as Sir James Mackintosh (1765-1832) called the Oxford Noetics, could not agree with him. They could not share his assessment of the role of logic in modern philosophical and scientific investigations. Stewart pointed out repeatedly that Aristotelian and scholastic logic were unfortunate relics of the past, superseded by the inductive logic of Lord Bacon. Various contributors to the Edinburgh Review turned Stewart's general philosophical and historical thesis into a severe indictment of education at Oxford. The university's cultivation of classical studies and logic

(7) Stewart 1854-60, first published in 1810 ; Belsham 1801 ; Darwin 1794-1796 ; Aarsleff 1967 ; Temkin 1946 ; Corsi 1980a and 1987b.

(8) (Copleston and Dudley) 1804; Whately 1821, 1822 and 1826 ; Copleston 1821 ; Baden Powell 1826 ; Hinds 1831 ; Stewart 1854-1860, first published in 1814. 
was seen as evidence of the backward and reactionary attitudes that prevailed there. (9)

Copleston could of course not condone this view of Oxford, and he attempted to refute the condemnation of logic on proper philosophical grounds. In a series of « replies » to the Edinburgh reviewers, and in a pamphlet Examiner Examined - which was published anonymously in 1809 and which was well known to Stewart, probably via Ward, though more or less neglected by other students of the period - Copleston defended the Oxford curriculum. He asserted that the allegation that Bacon introduced induction to suspend syllogism represented unphilosophical and «vulgar » opinion. No one doubted that induction was the method by which the " principles » or " premises » of reasoning were collected, but Aristotle and the schoolmen were mistaken only insofar as they selected premises with insufficient induction. Whenever men reasoned from premises they consciously or unconsciously followed rules and procedures that could only be evaluated through the employment of logical categories. (10)

Copleston's remarks were not directed against Stewart. Indeed, this pamphlet was designed primarily to castigate textbooks then used by students at Oxford. Yet Stewart was not pleased to see his views on logic described as «vulgar opinion ». The second volume of the Elements, published in 1814, contained a detailed denunciation of Aristotelian logic and the educational practices followed at Oxford. Stewart explained in the "advertisement » to the book that he intended « to aid my readers in unlearning the scholastic errors which in a greater or less degree, still maintain their ground in our most celebrated seats of learning ». That the reference to "seats of learning " was directed against Oxford and Copleston is confirmed by a footnote quoting, albeit incorrectly, the anonymous pamphlet of 1809 . In a letter to Copleston written shortly after the publication of the second volume of the Elements Ward invited him to answer « the direct attack upon the whole system » of education at Oxford, and to " seize the opportunity of making your debut in metaphysics ». Since he was «alluded to in terms of great civility ", Ward argued when referring to Stewart's critical footnote, it was Copleston's duty to defend the honor of the university as well as his own intellectual respectability. (11)

(9) Mackintosh 1821, p. 234. For a summary of the controversy, see Copleston 1811.

(10) Copleston 1809.

(11) Stewart 1854-1860, first published in 1814 ; Copleston 1840, pp. 16, 3 ; see also, pp. 14, 21. 
Copleston nonetheless declined to write a review of the new volume of the Elements for the Quarterly Review, a task that was performed by Wilham Rowe Lyall (17881857). A close analysis of this review, however, suggests that Copleston gave advice to the author. In view of the fact that the last paragraph contains a detailed discussion of technical point Copleston touched upon in his 1809 pamphlet, it could be argued that the assistance to Lyall extended to the writing of parts of the article. (12)

The polemical exchanges between Stewart and Copleston on the subject of logic, as well as Copleston's reluctance to state in full and explicit terms the points of agreement and disagreement with Stewart, have obscured the fact that Stewart and the scholars of Oriel essentially concurred in their evaluation of the role of the philosophy of the human mind in the development of modern science, and in contemporary philosophical, cultural, and political debates. Indeed, the second volume of the Elements was not designed to refute Copleston's advocacy of logic but rather to answer Jeffrey's charge that Stewart was engaged in the defense of a lost cause. The Edinburgh Review had published Jeffrey's review of volume one of the Elements in which he argued that man's increased power over nature was due to the unprecedented recent development of the natural and physical sciences. The philosophy of the human mind, despite Stewart's claim that it was founded on the sound inductive methods that characterized modern science, showed no sign of progress. Indeed, Jeffrey argued, no progress could be expected from a "science » based on pure observation, incapable of manipulating and dissecting the objects of its investigation, let alone of conducting experiments on them. (13)

Stewart was incensed at Jeffrey's remarks. He responded - in the "Preliminary Discourse » that constituted the preface to his Philosophical Essays and in the second volume of the Elements - that the analysis of the human mind contributed powerfully to clarifying the methods employed in science and helped establish rules for investigating new areas of scientific and social concern. Indeed, Stewart maintained, the philosopher was the only intellectual capable of performing so momentous a task. Excessive concentration on the problems and practices of their disciplines made students of the various branches of science or the liberal professions particularly unsuited to establishing the relative epistemological reliability of procedures for natural and social investigation.

(12) (Lyall) 1815.

(13) (Jeffrey) 1810. 
It is debatable whether Stewart substantiated his thesis adequately. James Mill thought not, even though he and many of his contemporaries regarded the last part of the second volume, devoted to the discussion of induction, the most interesting section. The Elements of the Philosophy of the Human Mind did in fact represent the only systematic epistemological survey of contemporary scientific debates available in Britain before 1830, when John Frederick William Herschel (1792-1871) published his Preliminary Discourse on the Study of Natural Philosophy. Contemporaries found in the Elements a detailed discussion of the most well-known scientific theories of the previous three decades, from the enormously popular work on chemical nomenclature by Louis Bernard Guyton de Morveau (1737-1809), Antoine Laurent Lavoisier (17431794), Antoine François de Fourcroy (1755-1809), and Claude Louis Berthollet (17481822) to the equally famous paleontological discourses of Georges Cuvier (1769-1832). (14)

Crucial categories of the philosophy of the human mind and « fundamental laws of belief », as Stewart chose to call the principles of common-sense philosophy, were shown to play a key role in modern scientific theorizing. "Experience» and " induction", Stewart pointed out, were not naive acts many self-styled but unphilosophical admirers of Bacon alleged. Every act of observation and every experiment implied "an interpretation of nature ». Stewart argued, in terms many epistemologists of today would regard as decidedly modern, that « without theory or, in other words, without general principles inferred from a sagacious comparison of a variety of phenomena experience is a blind and useless guide ». Every act of induction relied on a fundamental belief in the uniformity and constancy of natural laws. No investigation of natural phenomena could be undertaken without conscious or unconscious application of the principles of reasoning that regulated the activities of the human mind. The study of such principles was as essential to the development of science as was the investigation of the subject matter of each scientific discipline. (15)

The Quarterly Review and the Oriel dons sided with Stewart against Jeffrey. Lyall wrote in his earlier review of the Philosophical Essays that "we are told, by some persons, that when the pretensions of this boasted philosophy are sifted to the bottom, it will be found that it is incapable of making any substantial additions either to our knowledge or to our

(14) For a discussion of the scientific developments Stewart discussed, and the relevant bibliography, see Corsi 1983 and English language edition 1987b, ch. 1.

(15) Stewart 1845-1860, first published in 1814, p. 329. 
power ». He complained that the attention of some of his contemporaries was « wholly engrossed by the more brilliant and profitable pursuits of physical science " and he supported the «paramount utility » of the philosophy of the mind. The Oriel scholars, only too aware of the pressure on the English universities by Whigs and Radicals who accused the Anglican clergy of opposing the progress of knowledge, appreciated the implications of Stewart's defense of philosophy over the natural and the physical sciences. Their own defensive strategy included instituting chairs and readerships devoted to fashionable subjects like political economy and geology while refusing to make the study of these disciplines compulsory for students. The Noetics claimed that the education of the mind required concentration on the principles of reasoning, and it was therefore advisable to avoid early specialization. They justified their refusal to include new scientific subjects in the curriculum by pointing out that a liberal philosophical education prepared the student to embark upon any profession or discipline he might choose after three years at Oxford. Stewart's defense of the superiority of philosophy was thus turned into a defense of Oxford's system of education. (16)

\section{Science and Philosophy in the Second Volume of the « Elements »}

Several features of Stewart's philosophical investigation could be reinterpreted for use by Anglican apologists. His stand against associationist psychology and physiological materialism was eagerly incorporated into pamphlets, reviews, and treatises devoted to the refutation of the " errors " of the opponents of the Church of England. But the influence of Stewart on the Oriel Noetics was not limited to the borrowing of ideas to be used against theological and political opponents. Their differences with Stewart concerning the evaluation of the role of logic in modern philosophy notwithstanding, Copleston and Whately were impressed by the survey of modern science and contemporary epistemological debates contained in the last chapters of the second volume of the Elements. With appropriate modifications and reinterpretations, crucial features of Stewart's epistemology were deployed to assess the procedures of political economy.

It was Stewart's belief that the success achieved by the practitioners of various scientific disciplines in the last years of the eighteenth century

(16) (Lyall) 1811, pp. 5, 1. See also Corsi 1980a, part II and 1987a. 
and the early years of the nineteenth had given rise to the mistaken conviction that mathematical methods conferred mathematical certainty upon the results of all scientific and moral investigations. In the second volume of the Elements, the philosophy of Condillac, much praised in the first volume, was seen as responsible for the misleading view that since the superior certainty of mathematical conclusions derived from the perfect arrangement of mathematical language the problem was simply to provide every science with « signs equally perfect». His supporters boasted that Lavoisier had made explicit reference to the philosophy of Condillac when he introduced geometrical rigor into the arrangement of chemical elements and properties, thus revolutionizing the chemical nomenclature. The reform of the language of chemistry was at the time almost universally regarded as the outstanding feature of the chemical revolution. (17)

Stewart was convinced that the fashion for geometrical precision was responsible for wild metaphysical speculations based on materialistic ideas. It also reinforced the erroneous belief that the inductive science of the human mind was a mere combinatory art, as Gottfried Wilhelm Leibniz (1646-1716) had suggested. Stewart argued that Condillac and Leibniz had completely overlooked «the essential distinction between mathematics and the other sciences, in point of phraseology ». (18) It was, first, not the organization of the language that conferred certainty upon mathematical results. Secondly, the boasted certainty of mathematical results depended on the fact that the definition of mathematical objects coincided with their existence : in other words, the definition of a circle contained all the possible properties of the figure. By applying rigorous rules of deduction, the vincula provided by the axioms, the conclusions drawn from the definitions, and the combination of definitions predicated properties already implied in the definitions themselves. Thus, mathematical certainty was not about truth, but about consistency.

In mathematics, Stewart argued,

we have in view [...] not to ascertain truths with respect to the actual existencies, but to trace the logical filiation of consequences which follow from an assumed hypothesis. If from this hypothesis we reason with correctness, nothing [...] can be wanting to complete the evidence of the result ; as this result only asserts a necessary connexion between the supposition and the conclusion. (19)

(17) Stewart 1854-1860, first published in 1814, p. 104. See also Corsi 1987b, ch. 1.

(18) Stewart 1854-1860, first published in 1814, p. 106.

(19) Ibid., p. 114. 
In non-mathematical disciplines, definitions were concerned with matters of fact. The naturalist was bound to focus on certain features of the phenomena under investigation, in particular those within the reach of his senses and instruments. It was, of course, possible to deduce from these definitions, and to organize them according to the Euclidean model of axiomatic inference. However, the structure of the theory did not confer any higher degree of certainty upon the results obtained.

In other sciences, admitting that every ambiguity of language were removed, and that every step of our deduction were rigorously accurate, our conclusions would still be attended with more or less of uncertainty, being ultimately founded on principles which may or may not correspond exactly with the fact. (20)

Mathematical results and procedures enjoyed a superior state of credibility, according to Stewart, because of the perfect consistency of the conclusions from given definitions - or hypotheses, as he redefined them. Other sciences had to cope with the variety and complexity of natural phenomena, which could not be reduced to a few comprehensive and exhaustive definitions. The philosophical and moral sciences in particular could not be organized according to geometrical or mathematical models. In a long passage worth quoting in full in view of its relevance to later debates on the methodology of political economy, Stewart described how it was possible to build an axiomatic system for any science, moral and political ones included :

Hence it appears that it might be possible, by devising a set of arbitrary definitions, to form a science which, although conversant about moral, political, or physical ideas, should yet be as certain as geometry. It is of no moment whether the definitions assumed correspond with facts or not, provided they do not express impossibilities, and be not inconsistent with each other. From these principles, a series of consequences may be deduced by the most unexceptionable reasoning : and the results obtained will be perfectly analogous to mathematical propositions. The terms true and false cannot be applied to them, at least in the sense in which they are applicable to propositions relative to facts. All that can be said is, that they are or are not connected with the definitions which form the principles of the science ; and therefore, if we choose to call our conclusions true in the one case, and false in the other, these epithets must be understood merely to refer to their connection with the data, and not to their correspondence with the things actually existing, or with events which we expect to be realized in the future. (21)

(20) Ibid. pp. 114-115; cf. also p. 140.

(21) Ibid., p. 115. 
Thus Stewart acknowledged that the construction of an axiomatic-like doctrine consisting " of a series of propositions relating to moral, to political, or to physical subjects » was within the reach of the human mind. Yet the exercise could be of no utility : the only result achieved, he explained, would be to « display the ingenuity of the inventor ». (22)

Stewart was well aware that the distinction he was making between mathematics and the natural sciences - or any discipline concerned with natural phenomena - was open to many demurrals. The science of mechanics, for instance, was described by D'Alembert and by French physicists and philosophers as the perfect instance of a mathematical science successfully conversant with natural objects. Stewart admitted that mechanics, or theoretical astronomy, was bound to be used as an example against his view of science. How did it happen, a critic could have asked, that « although the peculiar force of that reasoning which is properly called mathematical, depends on the circumstance of its principles being hypothetical », yet the science of theoretical mechanics infallibly predicted the behavior of celestial and terrestrial bodies in motion ? Stewart, who had himself formulated the objection, was forced to concede " this remarkable, and indeed singular coincidence of propositions purely hypothetical, with facts which fall under the examination of our senses ». (23)

Stewart believed that he could solve the difficulty by defining mechanics as a hypothetical science (founded on few self-evident principles and axioms) that was also related in particular ways to natural objects. Practitioners of theoretical mechanics could disregard almost all the physical properties of the objects they studied, excluding disturbing circumstances from their treatment of mechanical problems and selecting those features that suited mathematical-like definitions. As Stewart explained,

[...] in the simplest applications of mathematics to mechanics or to physics, the abstractions which are necessary in the theory must always leave out circumstances which are essentially connected with the effect. In demonstrating, for example, the property of the lever, we abstract entirely from its own weight, and consider it as an inflexible mathematical line ; suppositions with which the fact cannot possibly correspond, and for which, of course, allowances (which nothing but physical experience can enable us to judge of) must be made in practice. (24)

(24) Ibid. p. 153.

(25) Ibid., pp. 154-155.

(26) Ibid., pp. 155-156. 
This passage could be construed as running against the main thesis of the second volume of the Elements, that it was possible but useless to build a science of moral or physical objects on a mathematical model. Indeed, not even Stewart was prepared to argue that the building of a "hypothetical » science of mechanics was an exercise that merely displayed the ingenuity of the human mind. It was not necessary for the definitions employed by the pure science of mechanics to include the full variety and concreteness of the phenomena described. No one could say that the conclusions of mechanical reasoning lacked certainty because the definitions did not provide an exhaustive description of the objects under investigation. Writers like Copleston and Whately, Senior and John Stuart Mill, who took Stewart's epistemology as the starting point for their discussion of the methodology of political economy, found the analysis of theoretical mechanics in the Elements a source of philosophical inspiration. The analogy between theoretical mechanics and theoretical political economy was to become a constant feature of the British debate on the epistemological status of economics.

Another feature of the second volume of the Elements was Stewart's insistence on the essential role played by language in the development of science. Even though he severely criticized the extreme length to which Condillac and his followers pushed the argument, he emphasized that the development of an unambiguous terminology was essential for scientific progress. Stewart was prepared to admit that political and moral sciences, as well as the physical and natural ones, were bound to benefit from perfecting their terminology. He even argued that the moral and political sciences could - in theory at least - reach a stage when « every word which we employ shall be as fixed and invariable in its signification as an algebraical character, or as the name of a geometrical figure ». Yet Stewart knew that hypothetical possibility did not mean possibility tout court. He was indeed convinced that, whatever the improvement to be expected from the perfecting of technical language, " not one step will have been gained in accelerating the era, so sanguinely anticipated by Leibniz and Condillac, when our reasoning in morals and politics shall resemble, in their mechanical regularity, and in their demonstrative certainty, the investigations of algebra ». (25) Stewart concluded that the goal of a political and moral science was not within human reach because of fundamental epistemological difficulties. This did not mean that he denied the profitability of a discourse concerned with political economy, or that he discouraged an exploration of the epistemological status of the disci- [discipline]

(25)Ibid., p. 107. 
pline. It is of course important to point out that we are referring to the epistemological strategy of the second volume of the Elements. We are not considering, for the moment, the statements on the method of political economy to be found in his Introductory Lectures, which in any case was not available to the majority of British intellectuals until 1855.

In the Elements, the discussion of selected features of the methodology of political economy was introduced in the context of Stewart's assessment of the comparative role of « theoreticians » and « practitioners » in the physical and social sciences and was part of his refutation of Jeffrey's strictures against the philosophy of the human mind. The appeal to the virtues of "experience " and the certainty of observation against the uncertainty of theories and theorizing were in Stewart's eyes clear indications of the low state of philosophical proficiency in contemporary Britain. As he pointed out, those who argued against theoretical systems " are themselves employed in amassing a chaos of insulated particulars, which they admit upon the slenderest evidence ». Every act of observation, or the calling upon a «fact» to confirm or refute a theory, implied a corresponding act of « interpretation » of nature. Stewart quoted with approval the view of the famous physician William Cullen (1710-1790) that « there are more false facts current in the world than false theories $\gg$. . (26)

The contrast between " theory » and «fact» was a regular feature of discussions between political economists - or political philosophers, as Stewart called them - and the political arithmeticians. The latter " arrogate to themselves exclusively the merit of treading closely in the footsteps of Bacon », whereas political philosophers were considered by the vulgar as " little better than visionaries, or, at least, as entitled to no credit whatever, when their conclusions are at variance with the details of statistics $»$. According to Stewart, the actual state of affairs in economic investigations disproved the claims of the arithmeticians. The facts accumulated by collectors of statistics were merely "particular results », and were rarely open to verification, while the " facts " investigated by the political philosopher were " exposed to the examination of all mankind; and while they enable him, like the general laws of physics, to ascertain numberless particulars by synthetic reasoning, they furnish the means of estimating the credibility of evidence resting on the testimony of individual observers $»$. Therefore, a little, if any, regard is due to a particular phenomenon, when stated as an objection to a con- [conclusion]

(26) Ibid., p. 327. 
clusion resting on the general laws which regulate the course of human affairs ». Moreover, since observation is always an act of interpretation, it was possible to argue that the naive observer is the worst possible source of information in any matter, and in particular on such complex phenomena as political and economic ones. As Stewart concluded, « instead of appealing to political arithmetic as a check on the conclusions of political economy, it would often be more reasonable to have recourse to political economy as a check on the extravagances of political arithmetic ». (27)

Can these statements be seen as contradicting previous passages concerning the " impossibility » of mathematical-like moral and political sciences, or can they be reconciled with them? Is the reference to the general laws that regulate the course of human affairs to be interpreted as indicating that it was possible to have a science of political economy? I would like to suggest that there was no contradiction, insofar as Stewart did not argue that political economy was or could ever become a well-defined, axiomatic-like discipline. Indeed, Stewart did not consider the results of deductions in political economy to be endowed with prescriptive certainty or authority. Though superior to the common-sense apprehension of reality, such conclusions derived from the analysis of the faculties of the human mind and the use of results obtained in a variety of scientific disciplines - agriculture, mechanics, physics, chemistry, natural history, and so on - thus they could never achieve the degree of credibility enjoyed by the mathematical sciences. Political economy could become only an effective method for the study and contemplation of the complexity of social phenomena. Stewart's discussion of the issue did not go any further. As he pointed out in his lectures,

The only infallible rules of political wisdom are founded ultimately on a knowledge of the prevailing springs of human action, and he who looses himself in the details of the social mechanism, while he overlooks those moral powers which give motion to the whole, though he may accumulate a mass of information highly useful in the pursuits of private life, must remain in total ignorance of those primary causes on which depend the prosperity and the safety of nations. (28)

A science of political economy could never reach a state of "geometric-like » organization, although developments in the science of the

(27) Ibid. pp. 331-332.

(28) Stewart 1854-1860, fist published in 1953, vol. I, p. 17. 
human mind could improve the analytical powers of the political economist, or, as he preferred, of the political philosopher.

\section{The Oriel Noetics and the Reshaping of Stewart's Epistemology}

Edward Copleston, Richard Whately, and Nassau Senior redeployed Stewart's arguments to support a position very much at odds with that reached in the Elements concerning the possibility of a science of political economy. Copleston's contribution was seminal to the debate, and his ideas permeate the writings of Whately, Senior, and other members of the Oriel community.

Copleston's contribution to early nineteenth-century philosophy and theology has failed to attract the attention of historians of the period. This is partly due to the fragmentary nature of his work and his reluctance to embark upon major literary projects. Copleston was asked, and sincerely intended, to write many books. However, as he candidly confessed to Whately when little time was left to regain lost ground, « my natural indolence and variations of health, and increasing cares of a practical kind will, I fear, stifle many an embryo plan, which I once hoped to develop and communicate to the world ». (29) His ideas on political economy and its methods were never systematically stated, but they can be reconstructed from passages in his polemical pamphlets against the Edinburgh reviewers and in his two letters to Sir Robert Peel (1788-1850) published in 1819. His comments on the methodology of political economy and science in general, shaped the views of Whately and Senior.

There is little doubt that at Oxford Copleston was the earliest advocate of political economy as an academic discipline. In 1810 he argued that the science had a « tendency, if rightly studied, to enlarge the mind », and proposed to introduce lectures on political economy as part of the course in modern history. But he remained opposed to the inclusion of political economy within the required curriculum for undergraduate studies. (30) His defensive strategy against radical pressure was based on making concessions toward modern scientific and political sciences - geology and political economy in particular - but both he 1965.

(29) Copleston 1851, p. 104 ; Jones 1968 ; Marshall 1956; Soloway 1969 ; Poynter 1969 ; Wills

(30) Copleston 1810, p. 172. 
and Whately well understood the difference between nominal and substantial concessions. Concessions to critics of the university who reproached the backwardness of its educational policy did not imply a serious commitment to change the state of studies at Oxford. (31)

Copleston's comments on political economy reveal that already in 1810 his objections to it as an element in undergraduate education were based on considerations other than whether or not it was a reliable science. Theoretical views of political economy, Copleston argued, had a tendency «to harden the feelings », and to « represent man as a blind part of a blind machine». This was precisely the way in which economic matters had to be viewed : «the frame-work of the great structure must, we know, be put together upon such [mechanical] principles »; but the contemplation of the whole machine was of no use to pupils who were destined to work all their lives at some wheel of the apparatus. Copleston believed that even from a practical point of view « the remedy of evils caused by the friction of the machine and by external accident, requires not that comprehensive view of its whole construction to be for ever present to the mind ». (32)

A clearer view of Copleston's ideas on the scope, objectives, and methods of political economy can be gained from his letter to Peel, the first one in particular. That Copleston had read the second volume of the Elements can be easily inferred from a comparison of Stewart's work with the relevant passages in Copleston's letter. He firmly placed the discussion of the methodology of political economy at the center of his discussion of the currency issue. He argued that no problem in political economy, nor indeed in any other science, could be approached without explicit reference to the method employed, and a full awareness of the relative role played by " theory » and " fact » in the investigation of natural and social occurrences.

When the first principles are brought in question, it is necessary to explain and vindicate the very elements of the science : at any rate, it is impossible satisfactorily to maintain an argument on political measures without pointing out the dependence of our positions on those first principles which are generally received as true. (33)

Moreover, differences of opinion in political economy were due to a variety of reasons, although their common denominator was the basic

(31) Corsi 1980a, pp. 151-153, and Corsi 1987a. ch. 9.

(32) Copleston 1810, pp. 173-174.

(33) Copleston 1819a, pp. 23. 
disregard of questions of method. Practical men in particular found it difficult to concentrate upon epistemological considerations. Their testimony concerning economic «facts» was very unreliable. Economic phenomena always appeared intimately connected with a « crowd of adventitious circumstances ». A process of analysis closely resembling the operation of the chemist was required in order to separate the pure "elements" and the basic features of phenomena from disturbing occurrences. However, in chemistry as well as in political economy, basic elements did not remain « pure » for long :

Those extraneous particulars which have by a laborious process been separated in order to exhibit the main ingredients in its unmixed form, soon rush together and become blended as intimately as before, when the scientific purpose is answered, and the powerful test which had expelled them is withdrawn. (34)

Copleston was much impressed by the analytical subtlety and logical rigor displayed by David Ricardo (1772-1823). He explicitly approved of Ricardo's views on rent, wages, and currency. Yet unlike Ricardo, Copleston believed that theoretical statements of political economy did not imply immediate political prescriptions but only theoretically motivated advice. Doctrinal elaboration was however of great assistance in examining the statements of practitioners and the pertinent « facts ». It is not surprising, therefore, that Copleston admired Ricardo's confutation of the theses defended by Samuel Bosanquet who quoted «facts» on trends in the foreign exchange in order to disprove the view that the depreciation of the currency favored the export of gold abroad. With Stewart, Copleston believed that no « fact » was certain when set against a theory. But he believed, contrary to Stewart, that political economy was a science concerned with a set of principles that enjoyed the utmost degree of certainty. Thus he confidently asserted that "profit is in mercantile dealings, what gravitation is in the system of the universe, and no problem is worth listening to, which supposes the absence of that universal principle ». (35) Bosanquet's " facts » were worthless once he implicitly assumed the existence of economic «agents » not pursuing profit. At the theoretical level, Copleston believed that in political economy it was possible to formulate a set of principles and definitions from which conclusions could be drawn by following rigorous and con- [consistent]

(34) Ibid., p. 4.

(35) Ibid., pp. 61-62. 
sistent logical procedures. Any fact allegedly contradicting the deductions from the "pure» elements of the science was to be accounted for in terms of «some circumstance behind which, if known, would account for the phenomena upon the ordinary principles $»$ of the science. (36)

It is important to note here that Copleston drew a firm line between the science of political economy and the wider field of economic legislation in general. As he emphasized in his second letter to Peel, his first letter had not suggested a prompt resumption of cash payment : on no account could doctrinal truth be put dogmatically into operation. The economic and social mechanisms, like any other mechanism, did not and could not coincide with the theoretical models which described them. In political economy as well as in mechanics, theoretically irrelevant «frictions » were of vital importance to the working of the machinery. Indeed, the actual disturbing circumstances deserved further and careful consideration: " frictions and disturbing forces may possible by care and skill be diminished; at any rate they deserve attentive study, as tending to illustrate the principles on which the several phenomena depend ». Clearly, Copleston had profited a great deal from a reading of the second volume of Stewart's Elements. (37)

Copleston disagreed, however, with Stewart's conclusions concerning the "science " of political economy. He saw that by applying the epistemological principles set out in the second volume of the Elements it was possible to develop a sophisticated theoretical account of economic machinery. The simplicity and universality of the " principles » of the science - such as the desire for wealth - and the application of rigorous logical procedures guaranteed its scientific and philosophic dignity. The epistemological rationale at the basis of Copleston's remarks on the methodology of political economy can be reconstructed through a comparison of works he planned and left to be executed by his pupils with those he himself completed - his 1809 pamphlet on logic, the two letters to Peel, and his Discourse on Necessity and Predestination (1821). Whately's Elements of Logic, published in the Encylopaedia Metropolitana and reprinted with much additional matter in 1826, was in fact the result of a collective enterprise by the Noetics. Copleston passed on to Whately his notes on logic, as well as the task of writing the book. Whately, who shared many of his teacher's virtues and vices, equitably applied the principle of the division of labor, and parceled out to John

(36) Copleston 1819b, p. 34.

(37) Ibid., p. 35. 
Henry Newman (1801-1890) and Nassau Senior some of the writing cores.

The works published by Copleston, Whately, and Senior - but also by other pupils of the Noetics like Baden Powell, Samuel Hinds, and Renn Dickinson Hampden (17931868) - offer ample evidence of indebtedness to the Elements. The points of difference that emerged were rarely indicative of a misunderstanding of Stewart's theses. The Noetics accepted all the basic principles of the epistemological program sketched in the Elements, with the exception of the evaluation of logic in contemporary science and philosophy. They differed from Stewart insofar as they felt that he failed consistently to deploy his own principles. One key feature of the Anglican apologetics formulated by the Noetics was an attempt not to oppose unreasonably contemporary philosophical and scientific development. The Church of England was more likely to survive the perilous era of the Reform Bill by carefully supervising the trend of change rather than by opposing reform and novelty at all cost. This line of caution guided their approach to science as well. Thus they agreed that Stewart was right when he pointed out that results in natural and moral sciences never achieved the certainty of mathematical conclusions. Yet results of some significance had been obtained in almost every area of physical and natural investigation. Moreover, contemporary public opinion believed that this was the case, and the Noetics were not prepared to undervalue the intellectual climate of their time. The real problem they faced was to regain the "philosophical» superiority, over the practitioners of science, thereby reinstating their « utilitarian » role in modern society. (38)

The Oriel dons were aware that there were many people in England ready to argue that it was the philosophy of the human mind that failed to cope with the unprecedented success of modern science, and not vice versa. Thus they granted the crucial epistemological distinction Stewart had pointed out between mathematics and the other sciences but noted that his assessment of the impossibility of transferring the geometrical model to other disciplines was already disproved by the progress of sciences like political economy. Political economy was seen by many as a successful «new science », and Stewart's indictment did not prevent political economists from putting forward their own views and from inquiring into the best methods to be followed in their discipline. Copleston, Whately, and Senior did not see why it was impossible

(38) Corsi 1980a and 1987a, Part I and II. 
to build a hypothetical science of political economy on the model of theoretical mechanics described by Stewart. The only qualification to be kept in mind, about which it was essential to convince political economists, related to the epistemological status of such theoretical constructions. Since political economy deals only with logical deductions from categories, its conclusions could not be immediately applied to the social and economic reality it purported to explain. The Noetics felt that this epistemological move saved the scientific validity of attempts to promote a better and more rigorous understanding of economic phenomena. At the same time, it preempted the aggressiveness of radical political proposals and represented a valid check against dogmatic plans of economic reform.

It is important that the disagreement over the role of logic in science, and the possibility of an axiomatic science of political economy, should not obscure the fundamental agreement between Stewart's philosophy and the Oriel epistemology. Indeed, Whately, Copleston, and Senior thought they were implementing the conclusions reached by Stewart, who had argued that a crucial distinction between mathematical and non-mathematical sciences was that the former started with definitions, whereas the latter reached their definitions after a period (of centuries, in many cases) in which the arts connected with the discipline were practiced without any systematic arrangement of the information collected.

Whately deployed Stewart's analysis of the historical formation of definitions in nonmathematical disciplines in his defense of the role of logical studies in contemporary culture and education. He pointed out that the fundamental mistake of logicians in the Middle Ages was to assume premises for their syllogisms which were not tested against a sufficiently large number of observations. In modern times rigorous logical procedures were proven to be of essential value to furthering the progress of science, since the accumulation of information in many fields of natural and social investigation provided sufficient material for good, or at least reliable, premises. Thus, he concluded, the study of logic, far from being a remnant of darker ages, as Stewart held, should become the focus of modern liberal education. (39)

Senior, Whately's pupil and the professional political economist of the Oriel group, could not see why Stewart's description of the historical formation of definitions in nonmathematical disciplines could not be

(39) Whately 1826, 1827 edn., Preface. 
applied to political economy. Men living in societies had always exchanged goods, legislated on the best means to promote private or national wealth, and acted according to a certain set of assumptions concerning the mechanism of the economic system. In the previous decades the general increase of knowledge and the spectacular success achieved in many branches of science provided the required cultural environment for approaching economic phenomena and their study in a systematic way.

The fact that the doctrines of political economy could not claim to explain or account for the highly complex spectrum of economic behavior and phenomena throughout history did not preclude an inquiry into its methods and an evaluation of the epistemological status of the results achieved. It seemed particularly important to explore the methodology of political economy at a time when economic doctrines appeared to be playing a growing role in policy decision and political economists disagreed among themselves as to the conclusions to be drawn from principles they agreed upon. During the 1820s, Copleston, Whately, and Senior, like Malthus in his 1827 essay on definitions, and later Whewell in his paper on the mathematization of political economy, argued that there was a consensus among political economists as to the basic categories and principles of economic discourse, even though strong disagreement prevailed concerning the correct theoretical definition of the categories employed.

Senior's chapter on ambiguous terms in political economy, appended to Whately's Logic, carried forward hints and suggestions made by Copleston in his 1819 letters as well as the indications provided by Stewart on the role of language in science. Senior argued that the prolonged observation of the complex phenomena which characterized economic activities produced a « few general propositions deduced from observation as from consciousness, and generally admitted as soon as stated ». However, the agreement to consider categories such as « rent», "wage », or « value » as the basic elements of any and all economic discourse did not prevent the practitioners of the discipline from drawing different and at times opposite conclusions from their premises. (40)

Stewart's and Whately's remarks on the use of language in science and on the development of an agreed-upon technical terminology were seen by Senior as essential guidelines for political economists. If they « had possessed a vocabulary of general terms as precisely defined as the mathematical » much debate and polemic would have been avoided.

(40) Ibid., p. 310. 
Moreover, a as the terms of this science are drawn from common discourse, and seldom carefully defined by the writers who employ them, hardly one of them has any settled and invariable meaning, and their ambiguities are perpetually overlooked» (41)

In his Introductory Lecture of 1826 Senior more fully developed the distinction between economic theory and economic practice put forward by Copleston in his letter to Peel. Once the ambiguity of language was cleared up, the problem remained of how to proceed, and of evaluating the degree of certainty of the results achieved. Senior was convinced that methodological naïveté was a major source of confusion among political economists. The majority of them failed to grasp the essential difference between the «theoretical» and the «practical» branches of the science. This was a crucial epistemological point in Senior's system. Since a science of all possible economic phenomena was clearly impossible and epistemologically absurd, it was essential to separate the pure elements from the mixture of disturbing causes that characterized their phenomenic appearance. Building a rigorous science of the elements of political economy meant restricting the field of competence and drawing a firm line between theory and practice. (42)

Copleston, following Ricardo, argued or hinted that the desire of profit was as universal as the law of gravitation. Senior, more modestly, pointed out that, " every person is desirous to obtain, with as little sacrifice as possible, as much as possible of the articles of wealth ». (43) This principle of the human consciousness, which commanded immediate assent from every human being, represented the guarantee of universality for the deductions drawn from other definitions assumed to be the principles of political economy - principles that described the elements connected with the production and distribution of wealth. Senior did not deny that the choice of definitions was "arbitrary », in the sense of the word used by Stewart. In nonmathematical sciences, definitions represented the result of a complex historical and analytical process, through which a series of statements emerged, and were agreed upon by the majority of those who practiced the discipline. It was clear, however, that the definition represented an « interpretation » of phenomena, as his teacher Whately was to acknowledge in one of his lectures I shall consider below. (44)

(41) Ibid. pp. 310-311.

(42) Senior 1827, pp. 36-37.

(43) Ibid, p. 47.

(44) Ibid. pp. 35-36. 
The political economist, Senior in this case, assumed that of all possible definitions of economic phenomena the ones he chose were the best suited to represent in the most simplified form the «pure» elements of economic processes. Rigorous deductive procedures were then applied to the definitions, and results were obtained that were true insofar as they did not imply contradiction of the premises, and deductions were correctly drawn. What kind of certainty was to be expected from results thus achieved ? Senior defiantly argued that the conclusions of political economy were endowed with no more or less « of all the certainty that can belong to any science, not founded exclusively on definitions ». By applying Stewart's analysis of scientific procedures, and indeed the very terminology he introduced, Senior argued that there was no reason to deny to theoretical political economy the degree of certainty to be expected from theoretical mechanics. As is well known, the explanation Senior provided of the relationship between the science and the art of economics underwent changes over the years. Yet his basic assessment of the procedures to be followed and of the epistemological reliability of the results obtained in the theoretical branch of political economy remained basically unchanged. (45)

Senior did not elaborate upon the sources of his epistemology. This is perhaps the reason why commentators have failed to point out the links between Senior's views of the science of political economy and the Oriel dialogue with Dugald Stewart. It could indeed be argued that Senior, as well as Whately and Copleston, did not feel the need to expand upon their debt to, and differences from, Stewart's work since their contemporaries were fully aware of the impact the Scottish philosopher had on contemporary debates on the methodology of political economy and of science in general. (46)

Yet, when in the early 1830s Richard Jones and William Whewell attacked the Oriel school the dependence of Noetic epistemology on the work of Dugald Stewart was openly acknowledged. Whately's " Ninth Lecture » (1832) on political economy was indeed a close commentary on the second volume of Stewart's Elements of the Philosophy of the Human Mind, defiantly deployed to refute Whewell's strictures against the Oriel school.

(45) Ibid., pp. 36. 41 ; Bowley 1937, pp. 42-65.

(46) Bowley 1937, as well as Levy 1970, failed to trace the roots of Senior's epistemological standpoint to Whately and Stewart. Schumpeter 1934 pointed out the importance of Whately's teaching for Senior (pp. 483-484), and emphasized the importance of Senior's contribution to economic theory (p. 574). Yet he failed to appreciate the relevance of Stewart's teaching for the Oxford school. See also Cowherd 1977 and Rashid 1985. 


\section{Richard Jones AND William Whewell : the Difficulties of AN AgREEMEnT}

Since the early days of their lifelong intellectual dialogue, Richard Jones and William Whewell discussed, and at times quarreled over, general philosophical and specifically epistemological issues. The strict baconism defended by Jones often clashed with Whewell's preoccupation with the epistemological status of physico-mathematical disciplines. A reader of French physicists and of Stewart, Whewell was concerned with defining the conditions of the necessity and universality of conclusions reached in sciences such as mechanics, which were conversant with natural phenomena but obtained results endowed with mathematical certainty. His philosophical investigations centered on the analysis of what he regarded as the a priori, self-evident conceptual elements in physico-mathematical disciplines, as well as the process through which «those principles which mechanics must borrow from experience » were incorporated into the scheme. In his first book, Elementary Treatise on Mechanics (1819), Whewell set for himself the task of establishing

what are the fewest and simplest principles [of mechanics ...] and how are we to reason from them. While it is acknowledged that the theory depends partly upon pure reason and partly upon experiment, there is still considerable difference of opinion as to which of its truths are necessary, and which contingent and observed. (47)

Whewell drew a line between the principles of statics (« nearly self-evident ») and those at the basis of mechanics, which required the analysis of « all the phenomena of motion » and the recourse to experiment. (48)

Jones objected strongly to the epistemological considerations developed in the preface to the Elementary Treatise. «I find fault with you for using the term necessary truth as applied to physical conclu- [conclusions]

(47) Whewell 1819, pp. III-IV. For Whewell's early philosophical reflections, see « Diary », 1817, in Trinity College, Cambridge : Whewell Papers. R.18.9.(2), f. $64 v$. I wish to thank the Master and Fellows of Trinity College for their permission to quote from the Whewell manuscripts, and I am grateful to the Librarian and the staff of the manuscript room for their valuable help. It is of some interest to point out that Whewell's earliest speculations on space as a priori condition of experience were suggested by his reading of Stewart's Philosophical Essays : see «Diary», R.18.9.(3), ff. 39v-46v On the relationship between Whewell and Jones, see also the letters printed in Todhunter 1876. vol. II ; De Marchi and Sturges 1973 ; see also the excellent study by Goldman 1983.

(48) Whewell 1819, p. Ix. 
sions $»$, he wrote to his friend in early 1820 . The principles of statics, as well as those of mechanics, " always must suppose some sort of experiment and induction » : he was ready to prove his point «vi et armis », that is to say by abuse and metaphysics ». (49) And this is what actually happened. A few days later, the two friends met in London, at Jones's lodgings. As Whewell wrote to a common acquaintance, the theologian Reverend Hugh James Rose (1795-1838) :

We took very strongly to metaphysics and happening to have made up his mind that the words «necessary truth » ought not to be placed in immediate contact, he became quite intolerant against a certain book in which the indecent conjunction happened to occur and abused the author of this unfortunate intimacy as if he had been guilty of two or three of the seven deadly sins. Not content with pouring forth all his own rage upon them, he went about to all his friends, protesting like a true parson (with your favour) that Church and King, the cause of sound doctrine and good practice, were all endangered by this unnatural union. I endeavoured in vain to appease him by chewing that neither reason nor custom had forbid the connexion. Three days was not sufficient to extinguish such a fire. (50)

The recipient of the letter, Reverend Rose, had little sympathy for Jones's baconism. In the early 1820 s Rose was decidedly leaning toward Coleridgean transcendentalism : to him, baconism and inductivism were incapable of reaching " higher » philosophical and theological truths. Yet he too found fault with Whewell's passion for deductive procedures, axioms, and definitions in physico-mathematical sciences. "You are a lost Heretic in metaphysics », Rose wrote to his friend in October 1822. However, he conceded that Whewell was not, « it seems, a regular follower of the Scottish School which has been passing away for the last twenty years, and [...] is ending in smoke ». To Rose, both Whewell and Jones were engaged in the fruitless attempt to prove the reliability and certainty of scientific results, the latter through a barren appeal to empiricism, the former through metaphysical investigation. (51)

The definition of the role of metaphysics, and indeed the very meaning of the term in modern philosophy, was a further point at stake in the correspondence of Jones and Whewell, and one which revealed Jones's preoccupation with the use of deductive procedures in political economy. The insistence on the value of metaphysical considerations in

(49) Jones to Whewell, n.d. [1818-1819]. Add. MSS c. 52(1), Trinity College, Cambridge.

(50) Whewell to Rose, n.d. [1820], Add. MSS 0.15.47(384), Trinity College, Cambridge.

(51) Rose to Whewell, 5 October 1822, Add. MSS a.211(134), Trinity College, Cambridge 
science, the emphasis on a priori, self-evident principles in scientific discovery and investigations were to him the rhetorical tricks employed by contemporary political economists to claim for their discipline an epistemological status equal to the one enjoyed by physical and mathematical sciences. In a letter to Whewell written in August 1822 , Jones stated the conviction that « metaphysics and reasoning had little to do with the origin of the Oeconomists ». (52) He challenged his friend, who appeared so keen to expand upon the " metaphysics of mathematics », by saying to him " what the devil can the pure metaphysics of political economy mean? [...] It is not the man who talks so mistaking the difficulties of language for the difficulties of the subject about which language is employed ». Was it not the case, in other words, that the refinement at the level of technical terminology, as well as the assumption of self-evident principles and definitions in the discipline, was nothing but «a confession of ignorance » of the complexity of economic phenomena? Jones, who was used not to measuring his language when philosophy and political economy were at stake, freely gave Whewell his opinion of the matter :

Metaphysics and metaphysical and all that brood are a set of mongrel cuts that run about and offer themselves to every blockhead who will use them, to play in the face of any one who puzzles him, besides standing sentry to drive away the conviction of his own ignorance whenever it approaches him. (53)

Whewell was « almost surprised at the fierce burning of your indignation against the poor word ", and invited his friend to keep pure philosophical concepts separate from the crude applications of political economists. Metaphysics, defined as «the examination of our intellectual powers and properties », was a legitimate province of the philosophy of mind. He had no difficulty meeting Jones's challenge, and he provided the definition his friend had asked for :

By the metaphysics of mathematics I mean the examination of the laws and powers of the mind on which their evidence depends, the analysis of their principles into the most simple form [...]. It is not easy to stick to the distinction between this and the logic of the science : but the latter examines the accuracy of your mode of deducing conclusions from your principles, and the former your way of getting your principles. (54)

(52) Jones to Whewell, 14 August 1822, Add. MSS c. 51(6), Trinity College, Cambridge.

(53) Ibid.

(54) Whewell to Jones, 16 August 1822, in Todhunter 1876, vol. II, pp. 48-49. 
Whewell did, however, agree with Jones that the expression « metaphysics of political economy » was incorrect, to say the least. Yet, he also pointed out to his friend that the discipline made use of "some abstract terms ", which referred « to the moral and intellectual qualities of man ». This peculiarity of political economy led some «blockheads » to believe that their discipline could be improved and developed by deploying metaphysical analysis to the definitions they regarded as the foundation of their deductive exercises. (55) This statement did not detract, however, from the fact that political economy, as well as mechanics, had to make reference to abstract terms, referring to man's moral and intellectual qualities - a view shared by Stewart, Copleston, and the Oriel school.

Whewell agreed with Jones that Ricardian economics, and contemporary economics in general, failed to establish the principles of the science on an appropriate inductive foundation. Political economists had not undertaken the study of all economic behaviors and situations, a task the students of mechanics had undertaken with respect to the phenomena of motion before formulating the principles of their science. Thus, the definitions political economists placed at the foundation of their deductive procedures were partial, inaccurate, and unreliable. Yet, unlike Jones, Whewell believed - at least until 1829-1830 - that deductive procedures were applicable to the science, and that there was a resemblance, at least a morphological one, between political economy and mechanics.

On March 2 and 12, 1829, Whewell read to the Cambridge Philosophical Society the first of a series of papers devoted to exploring the possibility of applying mathematics to the study of political economy. (56) There is no doubt that he had polemical goals in mind, when he subjected Ricardo's theory of rent to the test of his formulae. He was indeed careful to point out that he took Ricardo's premises for granted, without questioning their inductive foundation and scientific reliability. By showing that the results of strict mathematical calculation gave results opposed to the ones stated by Ricardo and his followers, he indicated that the premises themselves were faulty, and required further and more thorough investigation. As he wrote to Jones, « my object is to show the mode of applying mathematics so as to separate difficulties of calculations from difficulties of moral reasoning. To keep apart from business of reasoning up to principles and down from these - the former is induc- [induction]

(55) Ibid. p. 49.

(56) Whewell 1830. 
tion, and belongs to you, the latter is deduction », which, needless to say, Whewell felt it belonged to him. (57)

In view of his later, explicit, and indeed trenchant protestation against the hasty use of deductive procedures in political economy, it is important to point out that in his 1829 paper Whewell provided a description of the proper procedure to be followed in political economy, of which Copleston, Whately, and Senior would have approved. The reiteration of the proviso that he did not discuss the truth of the definitions and principles of the science did not prevent Whewell from stressing - for the moment, at least - the similarity of political economy to mechanics, in terms by now familiar to our discussion of the debate on the method of political economy in early nineteenth-century England :

It appears I think that the sciences of Mechanics and Political Economy are so far analogous, that something of the same advantage may be looked for from the application of mathematics in the case of Political Economy. And this must be remarked, that in this we are so far from claiming for it the rank of a science mathematically demonstrated, that we do not thus assert it to be a near approximation to the business of the world, any more than the doctrines of Mechanics are to actual practice, if we neglect frictions and resistance, and the imperfection of materials, and suppose moreover the laws of motion to be questionable. But we hold this method of investigation to be the best way of separating the theories which have been advanced, into the different kinds of truth, or of falsehood, of which they may happen to consists. (58)

Even though he firmly believed the « laws of motion » of political economy (that is, the principles adopted by Ricardo) to be utterly false, Whewell offered a model of reasoning in political economy that was no different from the one adopted by the Oriel school. The polemical intent and the paradoxical nature of his argumentation could not conceal the fact that Whewell regarded the model of investigation he was sketching as the best way to approach theoretical statements in political economy.

Jones received notice of his friend's paper early in 1829, although he did not read it until after its completion. He well understood the polemical rationale of the essay but was wearied by Whewell's predilection for deduction and mathematical procedures :

You are aware that I am not very sanguine as to the success of any attempt to make mathematical reasoning do more than point out logical

(57) Whewell to Jones, 5 March 1829, Add. MSS c. 51(62), Trinity College, Cambridge.

(58) Whewell 1830, p. 195. 
errors but I do not perceive that you profess to aim at much more - you should I think, however, repudiate more distinctly and earnestly than you have done any belief in the practical truth of the axioms and definitions of which you are tracing the necessary results [...] you should add a passage stating that you take the axioms about rent merely hypothetically in order to show the conclusions which right reasoning ought to have led those who assume them. You cannot do this too decidedly because in truth the axioms as applied generally to rents, are stark naught and apply only so far as they apply to a very limited class of rents. (59)

This exchange of letters occurred during the early months of 1829. Jones spent the remainder of the year and the entire following year revising and rewriting his book again and again, with Whewell's help. As far as Whewell was concerned, 1829 and 1830 were particularly busy years. He wrote several important reviews, expanded the horizon of his scientific concerns, and continued his study of German philosophy and theology. Surprising as it might appear, the documents available suggest that both Whewell and Jones were unfamiliar with the stand on political economy and philosophy defended at Oxford.

It was almost by chance that Jones read Whately's treatise on logic - he happened to read it only because a pupil asked to be taught the recent developments of the discipline. Jones was shocked to learn that the Oriel dons maintained a view of the method of political economy closely resembling the one he had ridiculed in his book as characteristic of the Ricardian school. Whately's logic, as a whole, did not displease Jones : "There is not much we should object to », he wrote to Whewell. He could not agree, of course, that all process of inference and deduction fell strictly into the province of logic as defined by Whately; he also criticized Whately's « foolish snear at those who think that inductive reasoning can ever be reduced to scientific form ».

It was Senior's contribution to his mentor's volume that sparked Jones's indignation :

Do I pray you get Whately's Logic [...] and to appendix p. 320. You will find some observations on terms by Senior beginning, «The foundation of political economy being a few general propositions deduced from observation and from consciousness and generally admitted as soon as stated, it might have been expected that there would be as little difference of opinion among Political Economists as mathematicians » [...]. He goes on so swimmingly that when he comes to rent he gets from consciousness and much observation as he deemed sufficient a notion that rent is always the result

(59) Jones to Whewell, 18 April 1831, Add. MSS c. 52(16), Trinity College, Cambridge. 
of some advantage which enables unequal profit to be made and proposes to extend the term to all the gains made in consequence of " any extraordinary powers of body and mind [...]». [...] I did not see Senior's nonsense till lately or I could hardly have kept my hands off him - as it is I think it likely that he may think the passage about « puerile attempts to make reasoning supply the place of knowledge »aimed at him. It was not, but he will be doing himself bare justice if he takes it all and more. (60)

And more was to come. Worried by the delay in the release of his book, Jones asked friends in the trade to make inquiries. It turned out that, with the exception of the few copies sent to potential reviewers and friends of the author, "none have been put in boards. » (61) In view of this discovery, the temptation to get his hands on Senior might have appeared irresistible to Jones. In the letter to Whewell quoted above, Jones hoped that Senior would have taken for himself the critique of the abuse of reasoning in political economy. It is therefore legitimate to argue that the unnumbered page between the table of contents and page one of Jones's text, which was aimed directly at the Oriel school, was inserted at the last possible moment, after Jones had discovered that there was still time to act.

It has been mentioned to me, that I have given no regular definition of the word Rent. The omission was not undesigned. On a subject like this, to attempt to draw conclusions from definitions, is almost a sure step towards error. A dissertation, however, on the use and abuse of definitions would be out of place here. I have pointed out the origin of payments made to the owners of the soil. I have tracked their progress. If any reader, during this enquiry, is really puzzled to know what we are observing together, I shall be sorry : but I am quite sure that I should do him no real service by presenting him in the outset with a definition to reason from. (62)

A few months later, the reading of Whately's Introductory Lectures on Political Economy suggested to Jones that a more explicit critique of the Oriel school should be devised, in order to discipline the mistaken philosophy of the Oxford colleagues :

What do you think of a few pages prefaced to the next volume, " On the use and abuse of definitions » showing first that we do know something of

(60) Jones to Whewell, 24 February 1831, Add. MSS c. 52(20), Trinity College, Cambridge.

(61) Jones to Whewell, 25 February 1831, Add. MSS c. 52(21), Trinity College, Cambridge.

(62) Jones 1831. 
their use and taking a goodly variety of instances of abuse and all from Whately's own book. (63)

There was clearly no danger that Joules would have been able to produce the " next volume » before the entire debate was over. Indeed, he never wrote it. The added passage to the Essay on the Distribution of Wealth was in fact the only public expression of the belligerant purpose Jones voiced to Whewell in their correspondence.

It was Whewell who took upon himself the task of criticizing the Oxford school, even though he did so in passages in which he carefully avoided a direct confrontation. Indeed, even when he was quoting sentences from the work of Senior, or voicing his resentment at Whately's logic, he refrained from quoting his source or identifying his opponents. The general public, as well as many historians, would have experienced some difficulty in deciphering cryptic allusions to and ironic paraphrases of works by the Noetics. Whewell did, however, make use of the several reviews he wrote in 1831 and 1832 to launch his guarded but powerful attack against the Oxford school. Informed by Whewell of his plans, Jones well understood the risk of going into open battle against the influential colleagues. " Do not unnecessarily provoke the Oxford men », he warned his friend, not fully comprehending that what he had already said in his own book was amply sufficient to irritate Whately and his pupils. (64)

\section{THE CONFRONTATION}

The reading of the diaries he started in 1817, of the works he published from 1819 to 1837, and of his correspondence with such friends as Jones, Rose, Julius C. Hare (17951855), and Herschel reveal the oscillations of Whewell's philosophical and epistemological reflections. The project of establishing the complementary role of a priori and experimental contents of physical, natural and social sciences developed through a variety of intermediary steps and of mental experiments with the solutions he found in classic philosophical works by John Locke, Thomas Reid, Stewart, Thomas Brown, Immanuel Kant, or even the Saint-Simonian literature. (65)

(63) Jones to Whewell, June 1831, Add. MSS c. 52(8), Trinity College, Cambridge.

(64) Jones to Whewell, 7 March 1831, Add. MSS c. 52(26), Trinity College, Cambridge.

(65) On the development of Whewell's philosophical thought, see Stoll 1929 ; Marcucci 1963 ; Butts 1965 and 1968 ; Laudan 1971 ; see also Yeo 1979, Elkana 1984, and Fisch 1985 for recent contributions to Whewell studies. 
Whewell had little hesitation in acknowledging the role of « metaphysics » in mature sciences such as mechanics. Appropriate modifications of Stewart's teaching, and his acquaintance with the work of the great theoreticians of French physics, reassured him of the merits and epistemological reliability of the application of mathematical methods to disciplines in which the definitions could be expressed in the simplest and most abstract form. The procedure of deducing from such definitions caused little problem. Greater difficulty was experienced when the philosopher had to account for the process which led to the formulation of definitions. How, in other words, could the principles of any science he obtained? Mechanics showed that it was possible to extract from the phenomena of motion fundamental laws capable of being expressed in few abstract definitions and axioms. Thus, contrary to Stewart, Whewell was convinced that it was possible to obtain necessary truth in disciplines conversant with natural phenomena. He also believed that lack of interest for the «logic of induction » represented the most serious shortcoming of British philosophy of the last decades.

During the years 1829-1833, the discussion with Jones, the reading of Herschel's Preliminary Discourse, the systematic exploration of contemporary histories of science and reports on the progress of a variety of physical and natural history disciplines decidedly bent Whewell's interest toward the problem of induction. This period in the development of Whewell's thought also marked the nearest point of agreement with Jones and Herschel he ever reached. Toward the mid 1830s, unable or unwilling to solve the puzzles of the "inductive logic », Whewell again emphasized the role of $a$ priori categories as the only guarantee of the necessity and universality of scientific results. Indeed it could be said that he abandoned all efforts to understand the conditions and epistemological status of inductive procedures deployed in developing disciplines such as geology, statistics, political economy, or evolutionary doctrines in biology. He retreated to the role of judge of the epistemological " maturity " of contemporary science, granting the dignified title of «full-blown sciences» to disciplines that answered the requirements of his philosophy, and withholding it from those he regarded as dangerous to his own view of philosophy, Christianity and social stability. (66)

During the years 1830-1833, Whewell felt optimistic about the prospects of successfully solving the problems of induction, and severely censured the Scottish philosophical tradition and the teaching of the Oriel school. He complained that « volumes upon volumes » had been

(66) Yeo 1979 ; Corsi 1987a, ch. 13. 
written on the philosophy of the human mind, to the absurd neglect of the intellectual processes that, in the last few decades, had produced such a tremendous increase in man's understanding of natural phenomena. With a clear reference to Stewart and Whately, Whewell expressed his hope for the time

when the received «philosophy of mind » shall have its leading chapters devoted to the most successful employments of the intellect : when the received «art of reasoning » shall contain something more than rules for deriving the consequences of assumed principles; and when "definitions » shall no longer be considered as the foundations of what we can know with regard to things altogether independent of the operations of human thought. It is the more remarkable that our prevalent metaphysics and logic should be so inapplicable to physics, when we observe that the whole atmosphere of literature rings with the name of «Lord Bacon », and with the paeans of « Inductive philosophy ». (67)

In his review of Jones's work on rent, published in July 1831, Whewell approached the issue of the method of political economy as a concrete instance of the wider philosophical problem of investigating scientific methodology. The faulty and dogmatic doctrines put forward by contemporary political economists and by the followers of Ricardo were the product of serious epistemological misconception. Whewell denied that mathematical and geometrical disciplines could provide reliable methodological guidelines for political economy. The discipline was still at the stage of collecting information on its subject-matter - a task, Whewell argued, that only Jones had undertaken with sufficient breadth and depth. Without quoting Senior, the author of the definition, Whewell criticized those who believed that « few facts of observation or of consciousness » could be taken as the foundation of political economy : " from these principles was deduced, as of course might be done from any such axioms whether true or false, a train of connected (and it might be easily have been consistent) conclusions, in the contemplation of which minds of logical propensities found an agreeable employment ». (68)

Whewell felt compelled to clarify and partially modify his own stand on the use of deductive procedures in political economy. In his 1829 paper on the application of mathematics to political economy, he had expressed the belief that, with the qualifications discussed above, political economy made use of abstract terms referring to « moral and intellectual

(67) Whewell 1831a, p. 377.

(68) Whewell 1831b, p. 53; see also Goldman 1983. 
qualities of man », and that there were points of similarity between the discipline and mechanics; in the 1831 review of Jones's book, he vigorously protested that this was not the case : "The vain attempt to establish at present an analogy between the most exact and complete of the physical sciences, and any existing speculations with regard to the interests, motives and actions of men, will end in useless and unmeaning subtleties and in idle and worthless paradoxes ». (69)

Whewell ended his denunciation of the methodological shortcomings of modern economists by quoting with scorn Senior's expression of marvel at the fact that there were still many differences of opinion among political economists, notwithstanding their use of definitions as abstract and precise as the ones employed by mathematicians. It is interesting to note that Whewell reproduced without acknowledgment the sentence by Senior that Jones had quoted with outrage in the letter discussed above. (70)

There was little doubt that the review of Jones's book was aimed at the Oriel school as much as to the followers of Ricardo. Few contemporaries involved in the debate on the method of political economy would have had any difficulty understanding who were the « logicians » losing their time with skillful manipulations from barren definitions, or who was the author of the sentence that (Whewell claimed) epitomized the faulty epistemology of contemporary political economists.

The page Jones added to his book, and the polemical reviews Whewell wrote in 1831, represented a provocation the Oriel men could not and would not overlook. Richard Whately, as friends and foes well knew, was a polemicist not to be undervalued, particularly at a time when his own ideas were under attack. His standpoint on church politics, on the Irish question, on the reform of the curriculum at Oxford, and on the critique of High Church theology he and his pupils were developing in the late 1820 s and the early 1830 s, displeased several representatives of the Anglican establishment. Thus Whately was not in a position to tolerate that his philosophical and political strategy was equated to the ones developed by radicals and the Ricardians. As might be expected, he did not fail to understand the polemical hints in Jones's book and in Whewell's writings. In the second edition of his Introductory Lectures on Political Economy, published in November 1832, Whately added the ninth lecture, which represented a powerful counterattack against the Cambridge opponents and a full-blown defense of

(69) Whewell 1831b, p. 55.

(70) Whewell 1831b, p. 8. 
Senior and of Oriel philosophy, expressed in terms highly indebted to Stewart's teaching.

Those who argued against « reasoning » in science, Whately maintained, were in fact arguing against the very use of reason in the solution of scientific and human affairs. Those who declaimed the use of definitions in political economy, he added, were in fact motivated by political considerations, which had nothing to do with the philosophy of science. They questioned the possibility of a rigorous science of theoretical political economy, in order to question the political measures suggested by those who studied the dramatic economic and social problems of contemporary Britain. Whately concentrated his reply to the Cambridge critics on the defense of the role of definitions and of logic his own logic - in science and political economy. He had little patience for the strictures of his opponents :

The only effect which declamations against the absurdity of using precise language in Political Economy will have on a man of well-trained understanding, will be to put him on his guard against such declaimers ; well knowing what description of persons are usually foremost in a mob clamoring against Police and Gas-light. (71)

The stand in favor of induction, taken by Jones and supported by Whewell in his review of his friend's book, was severely ridiculed by Whately. The problem of political economy was not the lack of facts. The idea that the discipline needed more and still more facts, and that the collection of miscellaneous information would have helped its progress, reminded Whately of someone attempting « to enlarge the prospect of a shortsighted man by bringing him to the top of a hill ». Whately did not deny that increased information was bound to improve the science. Yet he vigorously censured the contention by Jones that the accumulation of facts dispensed with clearly defining the rule and premises adopted in the science : "Had Bacon lived in the present day, I am inclined to think he would have made his chief complaint against unmethodized inquiry and illogical reasoning ». (72)

Leaving aside wit and personal invective, Whately embarked on a detailed defense of the method of political economy upheld by Senior. The themes and ideas that characterized Copleston's early writings on the subject were also mentioned. Only once were the works of Stewart

(71) Whately 1832, p. 242.

(72) Ibid., p. 237. 
referred to for a fuller discussion of the role of definitions in mathematical sciences. However, a comparison of the Introductory Lectures (the "Ninth Lecture» in particular) with the final chapters of the second volume of the Elements, discussed above, well illustrates Stewart's influence on Whately and on his colleagues at Oxford.

Jones argued that the major fallacy which modern economists were guilty was the use of definitions and deductive procedures at a time when the discipline still lacked essential detailed information concerning the historical development and variety of economic behaviors. Only a systematic vindiminatio of data, conducted in true Baconian fashion, would have helped the advancement of the discipline. Whately did not deny that the science was based on « facts », but found the standpoint defended by Jones decidedly naive :

Are we then to begin the study by collecting from all quarters - from History - Statistical accounts Travels, and all other sources, as great an amount as possible of all the facts that we can conceive to have any kind of bearing on the subject? And, after spending some years in accumulating a variety of information, are we, then only, to proceed to arrange the materials, and deduce from them some general principles ? (73)

According to Whately, political economy was a science that occupied a particular place in the spectrum of disciplines ranging from mathematics, the "purest » of all sciences, to geology, the discipline that required «the most exhaustive information ». Mathematics only required the formulation of « arbitrary definitions and postulates »; physical and natural sciences constantly referred to natural phenomena and the redefinition of principles, due to the historical acquisition of new information. Political economy was « distinguished from many other sciences ", being a "science which is founded on facts, and which has a practical application in reference to facts ; but which yet requires for the establishment of its fundamental principles very little information beyond what is almost unconsciously, and indeed unavoidably, acquired by every one $»$. (74)

Rigorous definitions from the «fundamental principles » guaranteed the consistency and epistemological reliability of the discipline. Yet the problem of the theoretical development of doctrines in political economy had to be carefully distinguished from the application of the theory

(73) Ibid., pp. 224-225.

(74) Ibid., pp. 226, 225. 
itself. In a passage strongly evocative of Stewart's remarks on the science of mechanics, Whately pointed out to the reader that

in order to make this application correctly, of course an accurate knowledge of the circumstances of each case is indispensable [...] in each practical question in Political Economy that may arise, we must be prepared to ascertain, and allow for, various disturbing causes, which may more or less modify the results obtained from our general principles ; just as, in Mechanics, when we come to practice, we must take into account the thickness, and weight, and the degrees of flexibility, of ropes and levers. (75)

Like Stewart, Whately expanded upon the unreliability of the data collected by the practitioners or the « unphilosophical» historian. The mass of material collected rarely provided any information of importance to the theoretical political economist. Whately also emphasized that no amount of so-called «pure facts » was free from conscious or unconscious theorizing. Historians, travellers, and practitioners of trades and industry were bound to describe phenomena and events that aroused their curiosity or confirmed their personal views on a particular class of phenomena. Moreover, the naive collector was often guilty of the worst kind of theorizing : "Man is so formed as to theorize unconsciously; facts will arrange themselves in his mind under certain classes, without his having any such design; and thus the materials he has been heaping together, will have been, as it were, building themselves up, into some, probably faulty, system, while he was not aware of the process going on in his own mind ». (76)

A further element of Stewart's philosophy, featured prominently in Whately's lecture as well as in his theological and philosophical works, was the concern with the role of technical language in science. Terms employed by political economists were usually drawn from common discourse. Words of common language served a plurality of purposes, and were often employed in a metaphorical sense. Their unavoidable use in political economy created considerable problems for the practitioners of the discipline : " the ambiguous use of a term may vitiate a whole train of reasoning, and thus establish an unsound general principle, which will lead to an indefinite number of errors in particular cases ». (77)

Whately did not doubt that the use of univocal definitions as premises of deductions in political economy represented the only means of

(75) Ibid., pp. 188, 227-228. Cf. Stewart 1854-1860, first published in 1814, p. 156.

(76) Whately 1832, p. 235.

(77) Ibid. p. 247. 
conferring logical rigor to the discipline. Terms adopted by political economists - such as «wage », « wealth», « rent»- were still taken from common language, but a rigorous definition of the sense in which they were used excluded the possibility of ambiguity and confusion.

The difference between Jones and Whewell on the one hand, and the Oriel men on the other, was deeper than disagreement over the role of definitions in science. To some extent, Whewell too was convinced by Stewart's remarks on the role of technical terminology and univocal definitions in science. Indeed, although Whewell rejected much of Stewart's teachings concerning the status of credibility of non-mathematical sciences, he always stressed the essential relevance of correct univocal definitions in science. Friends and colleagues approached him for suggestions concerning the best technical terms to be introduced in their discipline. Charles Lyell was indebted to Whewell for many of the terms he used in his geological works, and the tutor of Trinity was also responsible for the word «scientist», which eventually replaced the classic « natural philosopher ». Richard Jones discussed with Whewell the definitions of wealth provided by several contemporary political economists, as well as the definition he himself put forward.

The controversy between Whately and Jones over the use of definitions involved fundamental assumptions on the methodology of science and on the epistemological status of non-mathematical disciplines. Whately remained convinced that the basic tenets of Stewart's epistemology represented the final word on the subject of the methodology of science and took little notice of the process of discovery, since he was convinced that no "discovery » would ever reach the status of necessary truth. He agreed with Stewart that definitions concerned with " matters of fact» could never be « real » in the sense that mathematical definitions were real. To Whately, conclusions in the physical or natural history disciplines could never reach the status of universal and necessary truths pertaining to mathematical propositions.

Theoretical speculation was possible in every department of human investigation. Partial results were certainly obtained through the efforts of centuries of investigation or the casual discoveries of certain given properties of natural phenomena. These discoveries and results could be taken as the foundation for further theoretical elaboration, a process that inevitably involved the use of language, of definitions, and therefore of logical procedures. The results achieved by theoretical speculation never had immediate application to reality - not even in mechanics, the most perfect of the physical sciences. Whately maintained, with Stewart, 
that the attempt to reach necessary and universal truths in disciplines conversant with natural phenomena was bound to fail.

Jones and Whewell shared the conviction that too much attention had been paid to logical procedures and rules of consistency; inductive and experimental procedures leading to the perception of nomic patterns in nature deserved the greatest consideration by epistemologists and scientists. Unlike Whately, they believed that the study of « matters of fact» resulted in certain and universal conclusions, even though the growth of natural knowledge was slow and uneven. Whewell and Jones conceded that definitions played an important role in science and had to be univocal and consistent, but they also stressed that definitions had to be « real ».

Whewell did not wait long before taking up his pen again : a few weeks after the publication of Whately's "Ninth Lecture", Whewell published "On the Use of Definitions " in the Philological Museum, thus executing the plan that Jones had reserved for the second volume of his work. Whewell understood the deep rationale of Whately's standpoint. In contrast to his opponent's predilection for nominal and arbitrary definitions, he stressed the need for « real» definitions in the physical and natural sciences, and in political economy. As he put it, " it is impossible for us to possess exact definitions, except in proportion as our knowledge becomes general and systematic ». The revolution in chemistry achieved by Lavoisier was not due to the superior logical consistency of the reformed nomenclature, but derived from the establishment of «the true theory of the combination of elements with the acidifying principle ». (78)

Like any other scientific discipline, the study of social phenomena required the laborious collection of facts. In Whewell's eyes, the declamations characterizing the works of Stewart and Whately, against the use of information provided by travellers, traders, and statisticians in political economy, represented the clearest evidence of the sterility of their concept of science. Whately's " Ninth Lecture », in particular, revealed the dramatic shortcomings of the Oriel methodology of political economy. Indeed, he doubted that the Oriel epistemology was capable of founding a science :

What is this science? the science which thus attempts to trace the laws which determine the polity, the economical structure, the wealth of nations? Is it Political Economy? Probably : for the most celebrated teachers of that

(72) Whewell 1832a, p. 264. 
science speak with scorn of the prospect of collecting their principles by this slow and laborious process of observation and comparison. Their truths are to flow from the inexhaustible fountain of definition without previous knowledge and classification of facts. So that Political Economy must be a branch of metaphysics, in the same sense in which Bacon truly asserted that geometry is so. (79)

Whewell surveyed briefly the spectrum of scientific disciplines and classified those disciplines according to the certainty of results, achieved or achievable. He agreed with Stewart, and with his Oxford opponents, that in mathematics "definitions are themselves the first principles of our reasonings ». (80) However, he doubted that the peculiar constitution and procedures characterizing pure mathematics and geometry could become a model for all scientific endeavors. Once again, Whewell considered the special case offered by mechanics. If Stewart had referred to this discipline to stress its axiomatic-like structure and the need to take «frictions» into account when applications from the theory were sought, Whewell emphasized that the « definitions » employed in the science were not arbitrary and hypothetical like those in mathematics but required the establishment of a «true » relationship between the phenomena under consideration.

The approach to mechanics taken by Stewart and the Oxford Noetics failed to consider that the epistemological issue at stake was not just one of definition, but one of discovery as well :

Mechanics is the most perfect of the branches of mixed mathematics. It has also been the most happy in its definitions. But its happiness consisted in this; that mechanical philosophers resolved beforehand to employ words in such a manner, that those laws of nature which experience proved to be true, should be expressed in the simplest terms. Galileo and his opponents argued in asserting that bodies, falling by the action of gravity, were uniformly accelerated : but there was a real question between them, whether the velocity increased proportionally to the space, or to the time. When the latter appeared to be the fact, it was no longer contested that the expression should he appropriated to this law, and disjoined from the other. The definition followed the settlement of the dispute. (81)

Contrary to Stewart, Whewell was convinced that sciences conversant with natural phenomena could obtain and indeed had obtained the

(79) Ibid., p. 271.

(80) Ibid., p. 264.

(81) Ibid., p. 265. 
highest degree of epistemological reliability. This reliability was achieved when the definitions employed expressed true relationships between phenomena. Once those relationships had been "discovered", the science would develop through the deployment of rigorous procedures of deduction from the definitions (which were assumed to be the principles of reasoning in the science). In full agreement with Stewart, Whewell maintained that political economy had not reached this stage yet; he was doubtful that the discipline could be called a « science» in the foreseeable future. A science of "the modes of life », " the social structure », " the amount and distribution of the means of subsistence ", could be developed only after an exhaustive, worldranging historical analysis had been done of each and every form social relationships had taken and were taking :

[...] if our facts are laboriously collected and well compared, in the end we shall arrive at general classifications ; perhaps at general laws of connexion and causation. Voyages and travels, history and legislation, politics and statistics, will all be needed as materials for such a survey, and such a result. And when we have reached this point, then, indeed, terms to designate our classes, definitions to enable us to express our laws, will be wanted. (82)

Whewell, who had probably felt the burn of Whately's sarcastic remarks, concluded his answer to the « Ninth Lecture » with a parting shot equaling the polemical vigor and the wit of his opponent :

It may be said that a pickpocket loves to put out the lamps. It might be supposed that this dignified rebuke can proceed from none but some member of the venerable corporation of The Lamplighters : but it touches not us ; for we complain that these, our worshipful masters, do indeed set up an abundant supply of lamps of all sorts of sizes and shapes ; and ever and anon, when men complain of darkness, construct and put forth another and another; but that all this avails us not, so long as there is in these lamps not a drop of oil, no provision of enlightening matter. The way is just as dark as ever, and the only consequence is that, in addition to other lumber, we stumble over the lamps themselves. (83)

This time, Whewell did not conceal the target of his sarcasm : a footnote referred the reader to Whately's Lectures on Political Economy. The last sentence of Whewell's essay on the use of definitions marked the end of the hostilities between Oxford and Cambridge. It did not,

(82) Ibid., pp. 270-271.

(83) Ibid., p. 272. 
however, mark the end of the debate on the method of political economy, nor indeed the critical dialogue many representatives of British philosophy had with Dugald Stewart's work and the epistemological tradition he represented and reinterpreted. The polemic that pitted Whately and Senior against Whewell and Jones constantly referred to themes and topics Stewart had introduced in the debate on the method of science and of political economy.

\section{Conclusions}

Whately never answered Whewell's rebuttal. It is arguable that he never saw Whewell's article in the Philological Museum, a short-lived publication that never enjoyed much circulation outside Cambridge. In any event, the appointment to the archbishopric of Dublin late in 1832 plunged Whately into more mundane, and often dramatic, political occupations. The explosive situation in Ireland absorbed all of his energies for the rest of his life. New interests, ranging from phrenology to homeopathy, from the study of Australian aboriginal culture for natural theology purposes to the popularization of political economy, took up the little time he had left.

A man of stubborn views, Whately did not see much need to revise his basic philosophical standpoint to adapt it to the changing intellectual climate of the country. He simply redeployed the epistemological conclusions that he had reached in the $1820 \mathrm{~s}$ and the early 1830 s to criticize whatever trend in contemporary British intellectual life he perceived as opposed to his cultural and ecclesiastical policies. In more specific theological as well as epistemological matters, he kept the Oriel tradition of letting pupils fight his battles for him. As far as he himself was concerned, Whately took care of the many re-issues and re-editions of his early works and collected his occasional sermons in volumes of essays, in which he gave brief answers to his critics, usually by referring them to his previous works. He had little to add to what he had already said. (84)

Copleston and Jones shared similar destinies - their "natural indolence » and the offices to which they were appointed absorbed all of their time. Such was the case with many gentlemen clergymen of the time; philosophical and scientific pursuits rarely survived when appointments to a satisfactory office, a parish, or a bishopric came about. The

(84) Corsi 1987a, ch. 7 and 8. 
tradition of using authorship as a means of attracting patronage and achieving promotion within the Church or the state was still alive in the early and mid nineteenth century.

Whewell was certainly the most creative of the participants in the debate of 18311832. He constantly revised his philosophical views and kept up a steady effort in authorship. Promotion came late for him, as he lamented to a friend. (85) Whewell pursued his study on the application of mathematics to political economy. After 1832, however, he avoided all reference to Whately and the Oriel school. It should be pointed out that Whately's « Ninth Lecture » contained much that he found no fault with. Thus, for instance, he agreed with Whately and Stewart that the process of induction required the conscious or unconscious use of conceptual guidelines. The stress on induction as a process of mere accumulation and vindiminatio was clearly an overstatement motivated by polemical purposes. Even before writing his answer to Whately, in a letter to Jones Whewell praised the Saint-Simonians's insistence on « the conceptions which must exist in the mind in order to get by induction a law from a collection of facts; and the impossibility of inducting or even of collecting without this ». (86) Whately would have agreed with these sentiments, and indeed he said nothing much different in his « Ninth Lecture ».

It could be argued that Whately's position as Archbishop of Dublin put him out of reach of many critics, including Whewell. Indeed, although Whately was one of the most prolific authors within the ranks of the Anglican Church, his works aroused limited public debate. Thus his influence on the development of a variety of disciplines has been systematically underestimated and ignored by the historiography of the period. (87)

It would be wrong to interpret the epistemological development we have described or the debate we have reconstructed as a little-known marginal episode outside the mainstream discussions of the political economists and philosophers of the time. It could be argued that the study of the Oriel school and the controversies in which its representa- [representatives

(85) Whewell to Rose, 12 August 1836, 0.15.47(407), Trinity College, Cambridge : « It certainly is true that the Church should do something soon if she intends to do it at all for persons of your standing and mine who have been of any use to her, for we are no longer young men. I hope your time will come before long, for I have yet to make out my case by reforming the philosophy of the age [...] ».

(86) Whewell to Jones, 19 February 1832, in Todhunter 1876, vol. II, p. 141.

(87) Already in 1849 a critic in the Edinburg Review remarked that Whately's many books were widely read, but aroused less controversy than it might have been expected : Rosen 1849, p. 297. 
tives were involved would in itself represent a major corrective to historiographical trends obsessed (not always without reason) with impressive figures such as John Stuart Mill and Samuel Taylor Coleridge, or movements such as the philosophical radicals and the pro-German transcendentalists. It is noted that English intellectual life of the early and mid nineteenth century is described better in terms of parallel trends reflecting a variety of philosophical traditions, political preoccupations, social aspirations, and fears. (88)

As this study has shown, it is moreover impossible to project our contemporary disciplinary boundaries into the past, or to use them as reliable indications of disciplinary contexts in early and mid-nineteenth century Britain. The standpoints held by Copleston, Whately, Senior, Whewell and Jones during the debate on the method of political economy reflected a plurality of concerns and priorities. It was not appropriate to expand here upon the specifically theological or political dimensions of the debate described; it should, however, be pointed out that the investigation of the correct methodology for political economy was seen as part and illustration of the major philosophical problem of evaluating the status of credibility of contemporary science. The debate on the method of political economy, therefore, should not be understood as purely internal to the discipline.

The philosophical and epistemological problems discussed by the authors considered in this paper underlined serious concern over the conflict between traditional sources of cultural authority and a new emerging form of intellectual leadership. Men like Stewart and the Oriel dons well understood the long-term consequences of the scientific revolution they thought they were witnessing in the new chemistry, physics and astronomy, and in the advances of disciplines like comparative anatomy, crystallography, statistics and political economy, physiology, and (to some, at least) phrenology. The authority of the scientific method - the holy grail European philosophers hoped the next century would find - but more certainly the authority of technological inventions and the applications of «scientific » discoveries, were bound to obscure traditional theological or philosophical interpretations of man's place in nature and in society. Whatever doctrine claimed to be « scientific » was likely to attract the attention of present and future generations.

(88) There appears to be a tendency to simplify the diversity and vitality of cultural debates of the period by adopting misleading unifying interpretative categories such as "Broad Church» or "The Cambridge Network ». I have briefly discussed this issue in my review of S. Cannon 1978, Corsi 1980 and Corsi 1987a, ch. 13 and 14. 
The commentary on scientific and epistemological developments provided by Stewart in his works (for many years the only such commentary available in Britain) thus became an important element in the process of reorientation many individuals or groups of individuals felt they had to undergo in order to preserve their position of authority in society or in order to gain one in the process of the transformation of contemporary Britain. In the aftermath of the Napoleonic wars, many were convinced that it was essential to deal realistically with the new world they saw growing out of the social and political changes of the industrial revolution. This preoccupation was shared by Scottish intellectuals as well as Oxford High Churchmen, by philosophical radicals as well as Trinity College dons, by writers in the Edinburgh Review, the British Critic, the Westminster Review, and the Quarterly Review. It is not surprising, therefore, that Stewart's work appealed to sectors of the intelligentsia that were polarized in terms of political interests but that shared the belief, hope, or fear that more sophisticated intellectual tools, forged at the severe school of science, were likely to increase man's capability to understand and control social and political mechanisms. Thus, the debate between the Oriel Noetics on the one hand and Whewell and Jones on the other, was not an inter-factional squabble within the Anglican Church or the universities - the topics they were discussing and the solutions they were proposing were of great interest to a wider audience.

John Stuart Mill, for one, carefully read what Whately had to say on many issues, from ecclesiastical policies to logic, from rhetoric to theology, from philosophy to political economy. His father had been a pupil of Stewart. James Mill knew Stewart's works well, and paid attention to the epistemological sections of the Elements. He trained John Stuart to appreciate the importance of the methodological issues involved in modern scientific developments. The influence of Jeremy Bentham and the study of logical treatises alerted the younger Mill's attention to the model of consistency and necessary reason that logic offered to scientific and moral discourses.

His interest and admiration for Whately's logic reflected his concern for logical procedures ; the hint by Whately that induction itself could be expressed in syllogistic terms focused Mill's attention on what Whewell called - with different emphasis - the « logic of induction». Mill understood the problems facing those political economists and epistemologists who had read in Stewart a discussion of the limits and advantages of axiomatic-like constructions in disciplines conversant with natural phenomena. Like Whewell, he believed that the problem was 
to establish how to reason up to the definitions; contrary to the Cambridge don, he believed that logic itself could provide a satisfactory solution. The theory of the inductive syllogism he developed represented an historically brilliant attempt to solve the puzzle contemporaries saw as crucial to the further development of philosophy, and of the physical and moral sciences.

At the end of the 1820 s and in the early 1830 s, the advance of science, the popularity of science, and the growing belief that science was the universal panacea for social and economic problems appeared to Mill, Whewell, Herschel, and Jones, and also to men like Baden Powell, William Benjamin Carpenter, and Charles Babbage as demanding that the study of induction should be brought to the forefront of contemporary philosophy. Mill was aware of his limited firsthand knowledge of modern science. The solution of the problem of induction retarded the writing of the System of Logic. Mill profited a great deal from the reading of Herschel's Preliminary Discourse, as he was to take advantage from the study of Whewell's History of the Inductive Sciences.

On the issue of the method of political economy, Mill formed his own original views. Yet, in the polemical exchange of 1831-1832, he felt more sympathetic to Stewart as interpreted by Whately and Senior than to Whewell and Jones. In the original version of this paper, read at Kings College Cambridge in June 1981, I stated that Mill's essay « On the Definition of Political Economy; and on the Method of Investigation Proper to it » (significantly written in the autumn of 1832 and rewritten in the summer of 1833) provided further evidence of the "influence» of Stewart in the debate on Political Economy.

The only explicit reference to Stewart's Elements could not obscure, I then argued, the many passages in which Mill actually paraphrased the work of the Scottish philosopher. I understand that Professor Neal De Marchi has undertaken a close analysis of Mill's essay and has drawn a list of implicit quotations from Stewart to be found there. However, the reading of Whately's contribution to the debate on the method of political economy, and the reading of his "Ninth Lecture» in particular, makes it possible to argue that Mill had the works by Whately, as well as Stewart in his mind and in his hands when he was writing the essay. In view of the identity of many passages from Stewart that Whately and Mill referred to, it is legitimate to argue that Mill's essay represented his own response to the debate in which Whately was involved. Thus, internal and external evidence (the date of composition of the essay, immediately following the publication of the "Ninth Lecture »), confirm that a meaningful analysis of Mill's approach to the problem of the 
method of political economy requires that close attention be paid to his intellectual dialogue with Whately and his awareness of contemporary debates on Stewart and on epistemology in general. (89)

As was the case with the "influence " exercised by Stewart on the debate on political economy, Whately's "influence » on Mill should be assessed in terms of a close dialogue between two minds sharing several goals and a well-defined style of rationality, as well as a context of debates, challenges, and priorities not always taken into account by the historiography of the period.

It is therefore important to stress that a major reconstruction of the philosophical and cultural debates of early and mid nineteenth-century Britain is required in order to evaluate with the eyes of contemporaries, and not with the insight of today's disciplinary concerns, the many faces of their intellectual social, and political strategies. The one man/one problem approach to intellectual life of the time should give way to a systematic appraisal of populations of ideas and of social and intellectual actors, their interactions and disagreements, the dynamics of the reorientation and the change of outlook forced upon them by a period of great social and political transformations. This project requires that Stewart should be reinstated to the central, albeit controversial position his contemporaries felt he had rightly occupied for the first four decades of the nineteenth century.

\section{SUMMARY}

This article examines the debate on the method of political economy within Anglican circles during the early decades of the nineteenth century. At Oxford, the approach to political economy was conditioned by epistemological considerations stemming from the critical evaluation of Dugald Stewart's Elements of the philosophy of the Human Mind. The Oriel College intellectuals involved in the debate were worried by the rapid transformation of British society, and by the growth of sources of cultural authority independent from - if not opposed to - the Anglican Church and the Universities. The discussion on the method

(89) For a masterly and still challenging reconstruction of the intellectual dialogue Mill entertained with Stewart and Whately, see Kubitz 1932. It is not appropriate to expand in this essay on the relationship between Mill and Whately within the context of the debate on the method of political economy, a topic which deserves a separate study. 
of political economy thus involved wider dimensions of contemporary intellectual and social life.

Central to the Oxford debate was the parallel many saw existing between rational mechanics and theoretical economics. While accepting the claim to epistemological reliability made by political economists, the Oxford dons denied that the results achieved in the science could be immediately applied to social conditions: like the student of rational mechanics, the political economist had to take into account the « frictions » generated by existing social and political structures.

At Cambridge, William Whewell and Richard Jones looked with apprehension to the defense of political economy by their Oxford colleagues. In the late 1820s, the Cambridge intellectual reassessed the claim by the Ricardians and the Oriel College dons that political economy followed methodological guidelines similar to the ones adopted in rational mechanics. Political economy, they claimed, was too young a discipline to be ready for an axiomatic like formulation. Laborious inductions had to be undertaken before a satisfactory theoretical system could be built.

This article stresses the centrality of Dugald Stewart for the debate on the method of political economy in early nineteenth-century England. It is furthermore argued that the critical assessment of Stewart's epistemology was also crucial to the methodology of political economy developed by John Stuart Mill. The case-study discussed in this article calls for a critical re-evaluation of traditional accounts of early nineteenthcentury British philosophy, and intellectual life in general. 


\section{BIBLIOGRAPHY}

AarslefF H., The study of language in England, 1780-1860, Princeton, Princeton University Press 1967.

- From Locke to Saussure: essays of the study of language and intellectual history, Minneapolis, University of Minnesota Press 1982.

Akenson D. H., The Church of Ireland, ecclesiastical reform and revolution, 1800-1885, New Haven, Connecticut, Yale University Press 1971.

Belsham T., Elements of the Philosophy of the Mind, and of Moral Philosophy. To which is prefixed a Compendium of Logic, London, J. Johnson 1801.

BERG M., The machinery question and the making of political economy, Cambridge, Cambridge University Press 1980.

Bowley M., Nassau Senior and classical economics, London, G. Allen and Unwin 1937.

- Studies in the history of economic theory before 1870, London, Macmillan 1973.

Buchdal G., Inductivist versus deductivist approaches in philosophy of science, as illustrated by some controversies between Whewell and Mill, « Monist », 45, 1971, pp. 343-367.

Butts R. E., Necessary truth in Whewell's theory of science, "American philosophical Quarterly », 2, 1965, pp. 161-181.

- (ed.), William Whewell's theory of scientific method, Pittsburgh, University of Pittsburgh Press 1968.

- Whewell's logic of induction, in R. N. Giere and R. S. WestFall (eds.), Foundations of the scientific method. The nineteenth century, Bloomington, Indiana, Indiana University Press 1973, pp. 52-85.

Cannon S. F., Science in culture. The early Victorian period, New York Science History Publications 1978.

Checkland S. G., The advent of academic economics in England, « Manchester School of Economic and Social Studies », 19, 1951, pp. 43-79.

Curve J., Macaulay. The shaping of an historian, New York, A. A. Knopf 1973.

Collini S., Winch, D. and Burrow J., That noble science of politics. A study in nineteenth-century intellectual history, Cambridge, Cambridge University Press 1983.

Collini S., The tendency of things : John Stuart Mill and the philosophical method, in S. Collini et al., That noble science of politics, Cambridge, Cambridge University Press 1983, pp. 127-139.

Copleston E., The examiner examined; or, Logic vindicated. Addressed to the junior students in the University of Oxford, by a Graduate, Oxford, Printed for the author 1809.

- A reply to the calumnies of the Edinburgh Review against Oxford, 
containing an account of studies pursued in that University, Oxford and London, J. Cooke and Mackinlay 1810.

- A third reply to the Edinburgh Review, by the author of a reply to the calumnies of that Review against Oxford, Oxford and London, J. Cooke and Mackinlay 1811.

[Copleston E. and Dudley J. W. W.], Reid's Memoirs of the life of John Horne Tooke, «Quarterly Review », 7, 1812, pp. 318-328.

- A letter to the Right Hon. Robert Peel, on the pernicious effects of a variable standard of value, especially as it regards the conditions of the lower classes and the poor laws. By one of his constituents, Oxford and London, J. Murray 1819 a.

- A second letter to the Right Hon. Robert Peel on the causes of the increase of pauperism, and the poor laws. By one of his constituents, Oxford and London, J. Murray $1819 \mathrm{~b}$.

- An enquiry into the doctrines before the University of Oxford, with notes, and an appendix on the seventeenth article of the Church of England, London, J. Murray 1821.

Copleston E. (ed.), Letters of the Earl of Dudley to the Bishop of Llandaff, London, J. Murray 1840.

Copleston W. J., Memoir of Edward Copleston, DD, Bishop of Llandaff, with selection from his diary and correspondence, London, J. W. Parker and Son 1851.

Corsi P., Natural theology, the philosophy of science and the question of species in the works of the Reverend Baden Powell, D. Phil, thesis, Oxford University 1980 a

- Sciences in cultures, « Isis », 70, 1980 b, pp. 593-595

- Science and Religion. Baden Powell and the Anglican debate, 1800-1860, Cambridge, Cambridge University Press 1987 a.

- The Age of Lamarck, Berkeley and Los Angeles, University of California Press $1987 \mathrm{~b}$.

Cowherd R. G., Political economists and the English Poor Laws. A historical study of the influence of Classical Economics on the formation of social welfare policy, Athens, Ohio, Ohio University Press 1977.

De Marchi N. B. and Sturges R. P., Malthus and Ricardo's inductivist critics : four letters to William Whewell, «Economica », 40, 1973, pp. 379-393.

DARwin E., Zoonomia ; or, the laws of organic life, London, J. Johnson 1794-1796.

Einthorn L. J., Consistency in Richard Whately : the scope of his Rhetoric, "Philosophy and Rhetoric », 14, 1985, pp. 89-99.

Elkana Y., William Whewell, historian, « Rivista di Storia della Scienza », 1, 1984, pp. 149-197.

Fish M., Necessary and contingent truth in William Whewell's antithetical theory of knowledge, "Studies in the History and Philosophy of Science », 16, 1985, pp. 275-314.

Fontana B., Rethinking the politics of commercial society. The Edinburgh Review 1802-1832, Cambridge, Cambridge University Press 1984.

Giere N., and Westfall R. S., Foundations of the scientific method. The nineteenth century, Bloomington, Indiana, Indiana University Press 1973.

Goldman L., The origins of British "Social Science” : political economy, natural science, and statistics, 1830-1835, « The Historical Journal », 26, 1983, pp. 587-616.

Goldstrom G. L., Richard Whately and political economy in school books, 
1833-1880, « Irish Historical Studies », 15, 1966-1967, pp. 131-146.

Hitton B., Corn. cash and commerce. The economic politics of the Tory Governments 1815-1830, Oxford, Oxford University Press 1977.

Hinds S., An inquiry into the proofs, nature and extent of Inspiration, and into the authority of Scripture, London and Oxford, B. Fellowes and J. Parker 1831.

Hollander S., "William Whewcll and John Stuart Mill on the methodology of political economy », Studies in the History and Philosophy of Science, 14, 1983, pp. 127-168.

[Jefreey F.], Stewart's Philosophical Essays, « Edinburgh Review », 17, 1810, pp. 167-211.

Jones J. K. B., Anglican theological thought, 1750-1893, with especial refererrce to the pre-Tractarians, $\mathrm{Ph}$. D. thesis, Leeds University 1968.

KaVAloski V. K., The vera causa principle : an historico-philosophical study of a metatheoretical concept from Newton through Darwin, Ph. D. thesis, Chicago University 1974.

Kubitz O. A., Development of John Stuart Mill's System of Logic, "Illinois Studies in the Social Sciences », 18, 1932, pp. 1-310.

LaUdan L., William Whewell on the consilience of inductions, « Monist », 55, 1971, pp. 368-391.

Levy S. L., Nassau W. Senior (1790-1864), critical essayst, classical economist, and adviser of Governments, Newton Abbott, David and Charles 1970.

LoseE J., Whewell and Mill on the relations between philosophy of science and history of science, « Studies in the History and Philosophy of Science », 14, 1979, pp. 113-126.

[Lyall W. R.], Stewart's Philosophical Essays, « Quarterly Review », 11, 1811, pp. 1-37.

- Stewart's Philosophy of the Human Mind, «Quarterly Review », 12, 1815, pp. 281-317.

[Knight R. P., Playfair J. and Smith S.], Calumnies against Oxford, « Edinburgh Review », 16, 1810, pp. 159-187.

[Mackintosh J.], Stewart's Introduction to the Encyclopaedia, « Edinburgh Review », 35, 1821, pp. 220267.

Mackintosh J., Memoirs of the life of the Right Hon. Sir James Mackintosh, 2 vols., Second edn., London, E. Moxon 1836 ; First edn. 1835.

McDowell R. B., Public opinion and government policy in Ireland 1801-1840, London, Faber and Faber 1852.

McKerrow R. E., Method of composition: Whately's earliest Rhetoric, « Philosophy and Rhetoric », 11, 1978, pp. 43-58.

- Richard Whately on the nature of human knowledge in relation to ideas of his contemporaries, « Journal of the history of Ideas », 42, 1981, pp. 439-455.

- Archbishop Whately: human nature and Christian assistance, «Church History», 50, 1981, pp. 166-181.

MANIER E., The young Darwin and his cultural circle : a study of the influence which helped shape the language and logic of the first drafts of the theory of natural selection, Dordrecht, Reidel 1977.

Marcucci S., L'idealismo scientifico di William Whewell, Pisa, Università di Pisa, Istituto di Filosofia 1963.

Marshall B. R., The theology of Church and State in relation to the 
concern for popular education in England, 1800-1870, D. Phil. thesis, Oxford University 1956.

Olson R., Scottish philosophy and British physics. A study in the foundation of the Victorian scientific style, Princeton, Princeton University Press 1975.

Powell B., Rational religion examined, or, remarks on the pretensions of Unitarianism : especially as compared with those systems which professedly discard Reason, London, C. and J. Rivington 1826.

Poynter J. R., Society and pauperism. English ideas on poor relief, 1795-1834, London and Toronto, Roudedge and Kegan Paul, and University of Toronto Press 1969.

Pullen J. M., Malthus's theological ideas and their influence on his principle of population, « History of Political Economy », 13, 1981, pp. 39-54.

Rashid S., Richard Whately and Christian political economy at Oxford and Dublin, "Journal of the History of Ideas », 38, 1977, pp. 144-155.

- Richard Whately and the Struggle for rational Christianity in the mid-nineteenth century, « Historical Magazine of the Episcopal Protestant Church », 47, 1978, pp. 293-311.

- Edward Copleston, Robert Peel, and cash payment, « History of Political Economy », 15, 1983, pp. 249-259.

- Dugald Stewart, "Baconian" methodology, and political economy, «Journal of the History of Ideas », 46, 1985, pp. 245-257.

Restaino F., John Stuart Mill e la cultura filosofica Britannica, Firenze. La Nuova Italia 1968.

Richards G. C., Oriel College and the Oxford Movement, «The Nineteenth Century », 676, 1933, pp. 724-738.

[Rogers H.], Reason and faith : their claim and conflicts, « Edinburgh Review », 90, 1849, pp. 293-356.

Romilly S. H. (ed.), Letters to «Ivy» from the first Earl of Dudley, London, Longmans, Green and Co. 1905.

Schagrin M. L., Whewell's theory of scientific language, «Studies in History and Philosophy of Science », 4, 1973, pp. 231-240.

SchUmpeter J. A., History of economic analysis ; edited from manuscript by Elizabeth Boody Schumpeter, Oxford, Oxford University Press 1954.

Segerstedt T. T., The problem of knowledge in Scottish philosophy (Reid-Stewart-Hamilton-Ferrier), Lund Universitets Arsskrift Bd. 31, Lund, C. W. K. Gleerup 1935.

SENIOR N. W., An introductory lecture on political economy, delivered before the University of Oxford, on the 16th of December, 1826, London, J. Mawman 1827.

- Two lectures on population, delivered before the University of Oxford in Easter Term, 1828, to which is added, a correspondence between the author and the Rev. T. R. Malthus, London, Saunders and Otley 1828.

- An outline of the science of political economy, London, W. Clowes and Sons 1836.

Soloway R. A., Prelates and people. Ecclesiastical and social thought in England 1783-1852, London and Toronto, Routledge and Kegan Paul, and University of Toronto Press 1969.

Stewart D. (1854-1860), The Collected Works of Dugald Stewart, ed. by Sir W. Hamilton, 11 vols., Edinburgh, T. Constable : Vols. 2-4, Elements of the Philosophy of the Human Mind, vol. I first published 1792, vol. II first published 1814, vol. III first published 1827 ; vol. 5 : 
Philosophical Essays, first published 1810; Vols. 8-9: Lectures on Political Economy, first published 1855-1856.

Stoll M. R., Whewell's philosophy of induction, Lancaster, Pennsylvania Lancaster Press 1929.

TEMKIN O., The philosophical background to Magendie's physiology, «Bulletin of the History of Medicine », 20, 1946, pp. 10-35.

TODHUNTER I., William Whewell. An account of his writings with selections from his literary and scientific correspondence, 2 vols., London Macmillan 1876.

Walsh H. T., Whewell on Necessity, «Philosophy of Science », 29, 1962, pp. 139-145.

- Whewell and Mill on induction, « Philosophy of Science », 19, 1962, pp. 279-284.

WARD W. R., Religion and society in England, 1790-1850, London, B. T. Batsford, 1972.

Waterman A. M. C., The ideological alliance of political economy and Christian theology 17891833, « Journal of Ecclesiastical History», 34, 1983, pp. 231-243.

Whately R., The Right Method of Interpreting Scripture in what relates to the Nature of the Deity, and his dealings with mankind, illustrated, in a Discourse on Predestination, by Dr. King, preached at Christ Church, before the House of Lords, May 15, 1705, with notes by the Rev. Richard Whately, Oxford and London, Baxter and Murray 1821.

- The use and abuse of party feelings in matters pertaining to religion, considered in eight sermons preached before the University of Oxford, in the year 1822, at the lecture founded by the late Rev. John Bampton, M. A., Oxford, Clarendon Press 1822.

- Elements of Logic, comprising the substance of the article in the Encyclopaedia Metropolitana: with add tions, \&c., London, B. FeIlowes 1826.

WheWELl W., An elementary treatise on mechanics; designed for the use of students in the University, Cambridge, J. Deighton and Sons 1819.

- Mathematical exposition of some doctrine of Political Economy, «Transactions of the Cambridge Philosophical Society », 3, 1830, pp. 191-230.

- Modern science - inductive philosophy, «Quarterly Review », 45, 1831 a, pp. 374-407.

- Jones - On the Distribution of Wealth and the Sources of Taxation, "British Critic », 19, 1831 b, pp. 41-61.

- On the use of definitions, «Philological Museum », 2, 1832 a, pp. 263-272.

- An Introduction to Dynamics, con taining the Laws of Motion and the First Three sections of the Principia, Cambridge and London, J. and J. J. Deighton and J. W. Parker 1832 b.

- On the nature of the truth of the laws of motion, "Transactions of the Cambridge Philosophical Society», 5, 1834, pp. 149-172.

The Mechanical Euclid, containing the Elements of Mechanics and Hydrostatics demonstrated after the manner of the Elements of Geometry; and including the propositions fixed upon by the University of Cambridge as requested for the degree of B. A., to which is added, Remarks on Mathematical reasoning and the Logic of Induction, Cambridge and London, J. and J. J. Deighton, and J. W. Parker 1837.

William F. M., Aristotelische Er-[Erkenntnislehere] 


\section{4}

kenntnislehere bei Whately and Newman, Freiburg im Breisgau, Herder 1960.

WiLlis W. B., Ecclesiastical reorganization and Church extension in the Diocese of Llandaff, 1830 to 1870, M. A. thesis, Swansea University 1965.

WINCH D., The system of the north: Dugald Stewart and his pupils, in S. ColLINI et. al., That noble science of politics, Cambridge, Cambridge University Press 1983, pp. 23-61.

YeO R., William Whewell, natural theology and the philosophy of science in mid-nineteenth century Britain, « Annals of Science », 36, 1979, pp. 493-516.

- An idol of the market-place: Baconianism in nineteenth century Britain, « History of Science », 23, 1985, pp. 251-298. 